\title{
A new coral reef province in the Gulf of Carpentaria, Australia: Colonisation, growth and submergence during the early Holocene
}

\author{
Peter T. Harris ${ }^{\text {a,*}}$, Andrew D. Heap ${ }^{\text {a }}$, John F. Marshall ${ }^{\text {a }}$, Malcolm McCulloch ${ }^{\mathrm{b}}$ \\ a Marine and Coastal Environment Group, Geoscience Australia, GPO Box 378, Canberra ACT 2601, Australia \\ ${ }^{\mathrm{b}}$ Research School of Earth Sciences, Australian National University, Canberra ACT 0200, Australia
}

\section{A R T I C L E I N F O}

\section{Article history:}

Received 25 November 2007

Received in revised form 24 January 2008

Accepted 5 February 2008

\section{Keywords:}

coral reefs

$\mathrm{U} / \mathrm{Th}$ dating

sea level

Quarternary

reef growth

Holocene

\begin{abstract}
A B S T R A C T
Multibeam sonar mapping, drill cores and underwater video data have confirmed the existence of a previously unknown coral reef province in the Gulf of Carpentaria, Australia. Seven reefs, comprised of coral limestone that support living corals have been mapped so far and as many as 50 other reefs may exist in the region. U/Th ages show that reef growth commenced shortly after limestone pedestals were submerged by rising sea level around $10.5 \mathrm{kyr}$ BP, making them the oldest Holocene reefs known in Australia. Reef growth persisted for $\sim 2.0 \mathrm{kyr}$ but it had ceased at most locations by $\sim 7.0 \mathrm{kyr}$ BP. Measurements of reef growth rates $\left(0.95\right.$ to $\left.4 \mathrm{~m} \mathrm{kyr}^{-1}\right)$, indicate that the reefs were unable to keep pace with contemporaneous rapid sea level rise $\left(>10 \mathrm{~m} \mathrm{kyr}^{-1}\right)$, which is consistent with a "give up" reef growth history. Core samples from reef platforms demonstrate that Pleistocene limestone is exposed at depths of 27 and $30 \mathrm{~m}$ below present mean sea level. These depths represent regionally significant phases of reef growth during a prolonged sea level still stand. We conclude that the reefs are therefore mostly relict features, whose major phase of growth and development relates to an earlier, pre-Holocene sea level still stand.
\end{abstract}

Crown Copyright @ 2008 Published by Elsevier B.V. All rights reserved.

\section{Introduction}

Most of our knowledge of the distribution of coral reefs has been discerned from nautical charts, aerial photographs and satellite images. Our picture of the global distribution of coral reefs is incomplete because the distribution of coral reefs in turbid water, or with surfaces below the limits of remote optical detection, is unknown. Submerged coral reefs not detectable using remote optical techniques occur not only in locations adjacent to charted reefs but also, as the present study demonstrates, in places where they were previously thought not to exist.

In Australia, coral reefs of the Great Barrier Reef (including Torres Strait) and Ningaloo Reef provinces are very well studied (Veron, 2000), and their growth histories and character are well established (e.g., Woodroffe et al., 2000; Collins et al., 2002; Hopley et al., 2007). Smaller reef complexes such as the Houtman-Abrolhos Reefs in Western Australia (Collins et al., 1996; Wyrwoll et al., 2006), Sahul Banks and Ashmore and Cartier Reefs in the Timor Sea (Heyward et al., 1997), Lord Howe Island, Middleton and Elizabeth Reefs in the Tasman Sea (Woodroffe et al., 2004, 2005), and Cocos-Keeling and Christmas Islands in the Indian Ocean (e.g., Woodroffe et al., 1991, 1994) have received less treatment but their post-glacial history is still reasonably

\footnotetext{
* Corresponding author. Geoscience Australia, GPO Box 378, Canberra ACT 2601, Australia. Tel.: +612 6249 9611; fax: +61262499920.

E-mail addresses: Peter.Harris@ga.gov.au, pharris@aapt.net.au (P.T. Harris).
}

well known. Until our study, few modern coral reefs had been documented in Australia outside of these regions.

Identification of submerged coral reefs at locations around Australia outside of the known reef provinces has been made possible through the utilisation of multibeam sonar. In 2003, three prominent seabed features in the southern Gulf of Carpentaria, denoted on nautical charts as shallow banks, were mapped with multibeam sonar. The results revealed previously unknown submerged coral reefs (sensu Macintyre, 1972) located at around 18-30 m water depth (Harris et al., 2004). The submerged coral reefs exhibited classic reef geomorphology, and extensive surfaces showed that they mostly formed when sea level was $\sim 30 \mathrm{~m}$ below its present position. Sparker seismic profiles showed that the coral limestone bioherms were underlain by an acoustic basement with positive relief (Harris et al., 2004). A series of 3-4 lateral ridges on the reef margins indicated that coral growth and deposition of carbonate was associated with repeated submergence, most likely throughout the Quaternary. A live specimen of Turbinaria (plate coral) was recovered from one location and underwater video footage showed that live hard corals also occurred at seven other locations. The fact that these submerged reefs support live hard corals is evidence for a "give-up" growth history (cf., Neumann and Macintyre, 1985) relative to sea level rise. A "give-up" growth history involves slow reef growth following submergence of the reef pedestal during transgression, followed by limited to zero growth under present high sea level conditions.

The existence of three submerged reefs in the southern Gulf of Carpentaria raises several questions, namely: how many other submerged 
coral reefs occur in the southern Gulf of Carpentaria? When was the latest phase of "keep-up" coral reef growth? Why did the corals stop growing at a rate comparable to post-glacial sea level rise?

The principal aim of this study was to map several other banks in the southern Gulf of Carpentaria using multibeam sonar to ascertain if they are also submerged reefs. The second aim was to recover core samples from a representative number of submerged reefs to establish their composition and growth history from radiometric dating. We then use this information to compare this growth history with the reasonably well-established growth histories of other reef provinces from Australia and elsewhere and to explore possible mechanisms for the "give-up" growth history exhibited by the southern Gulf of Carpentaria submerged reefs.

\section{Study area - Gulf of Carpentaria}

\subsection{Physiography and sedimentology}

The Gulf of Carpentaria is a $414,000 \mathrm{~km}^{2}$ tropical epicontinental seaway in northern Australia that extends from Cape Wessel in the west to Torres Strait in the east (Fig. 1). Water depths attain $>70 \mathrm{~m}$ in the eastern-central Gulf, but mostly the seabed forms a relatively flat, featureless plain between 50 and $60 \mathrm{~m}$ water depth (Torgersen et al., 1983). The Gulf is connected to the Arafura Sea across the $53 \mathrm{~m}$ deep Arafura Sill and to the Coral Sea across the $12 \mathrm{~m}$ deep Torres Strait (Harris, 1988).

Coral reefs cover $140 \mathrm{~km}^{2}$ in the Gulf (www.reefbase.com), made up of emergent fringing reefs principally located around Groote Eylandt, Wessel Islands and the western coast (Heap and Harris, 2008). Before the study of Harris et al. (2004), no patch coral reefs were known in the Gulf.

Throughout the Quaternary, the Gulf of Carpentaria has been repeatedly submerged and exposed by fluctuating sea level (Fig. 2A). The closed basin within the Gulf was transformed into a lake during times when sea level was below the depth of the Arafura Sill (Nix and Kalma, 1972; Torgersen et al., 1983, 1988). At its greatest extent, Lake
Carpentaria may have been as much as $500 \mathrm{~km}$ long, $250 \mathrm{~km}$ wide and $15 \mathrm{~m}$ deep (Jones and Torgersen, 1988). When the Arafura Sill was breached by rising sea level, the Gulf became a brackish to marine, lagoon environment. Recent studies of the late-Quaternary history of the Gulf have shown that this repeated exposure and submergence has been recorded in the bed sediments, which form basin-wide alternating marine and lacustrine sequences (Torgersen et al., 1983, 1988; Chivas et al., 2001). During the most recent post-glacial sea level rise, the sill in Torres Strait was breached around 9 kyr BP (Harris, 1994).

Seabed sediments in the Gulf of Carpentaria can be broadly divided into two distinct zones that trend generally parallel with the coast: 1) a nearshore zone $(<20 \mathrm{~m})$ of active sedimentation; and 2$)$ an offshore zone of comparatively low sedimentation that characterises the remainder of the flat gulf floor. Relict sediments are common, and comprise mixtures of: poorly-sorted, stained and fractured quartz; ferruginous or calcareous pisoliths; ooids; abraded, yellow-brown stained foraminifera; poorly-sorted relict terrigenous mud; and locally derived carbonate sand, with calcareous muddy sands generally occurring in central gulf regions (Jones, 1986, 1987; Jones and Torgersen, 1988). Significantly, the southern Gulf of Carpentaria represents Australia's largest shelf province of terrigenous-dominated sediment, covering an area of $100,000 \mathrm{~km}^{2}$ where seabed sediments have an average non-carbonate content of $>50 \%$ (Fig. 3). The coastline of the southern Gulf is characterised by prograding deltas and chenier plains, indicative of considerable sediment discharge throughout the Holocene (Jones et al., 2003). Because the discharge of these rivers is very great during the summer monsoon, fluvially-derived sediments contribute a major part to the modern southern Gulf sediment budget.

\subsection{Oceanography and climate}

The tidal regime of the Gulf of Carpentaria is mixed-semidiurnal in the north to mainly diurnal in the south (near Mornington Island; Fig. 1; Easton, 1970; Church and Forbes, 1981, 1983). Wind-driven and baroclinic circulation results in a poorly-defined, clockwise rotating gyre within the Gulf, with currents attaining $8 \mathrm{~cm} \mathrm{~s}^{-1}$ (Wolanski,

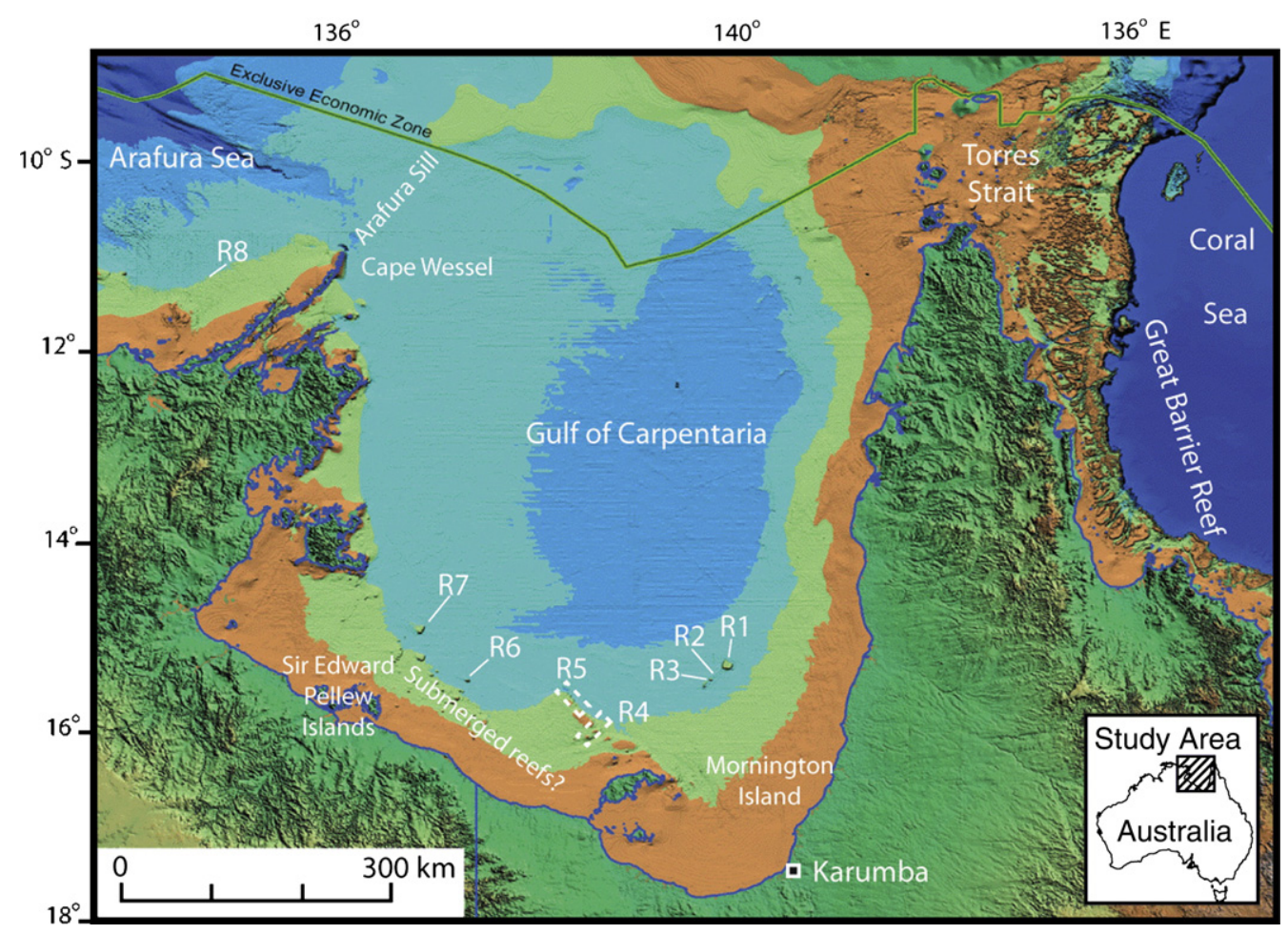

Fig. 1. Location map of submerged coral reefs examined in this study in the southern Gulf of Carpentaria. Locations cited in the text are indicated. 

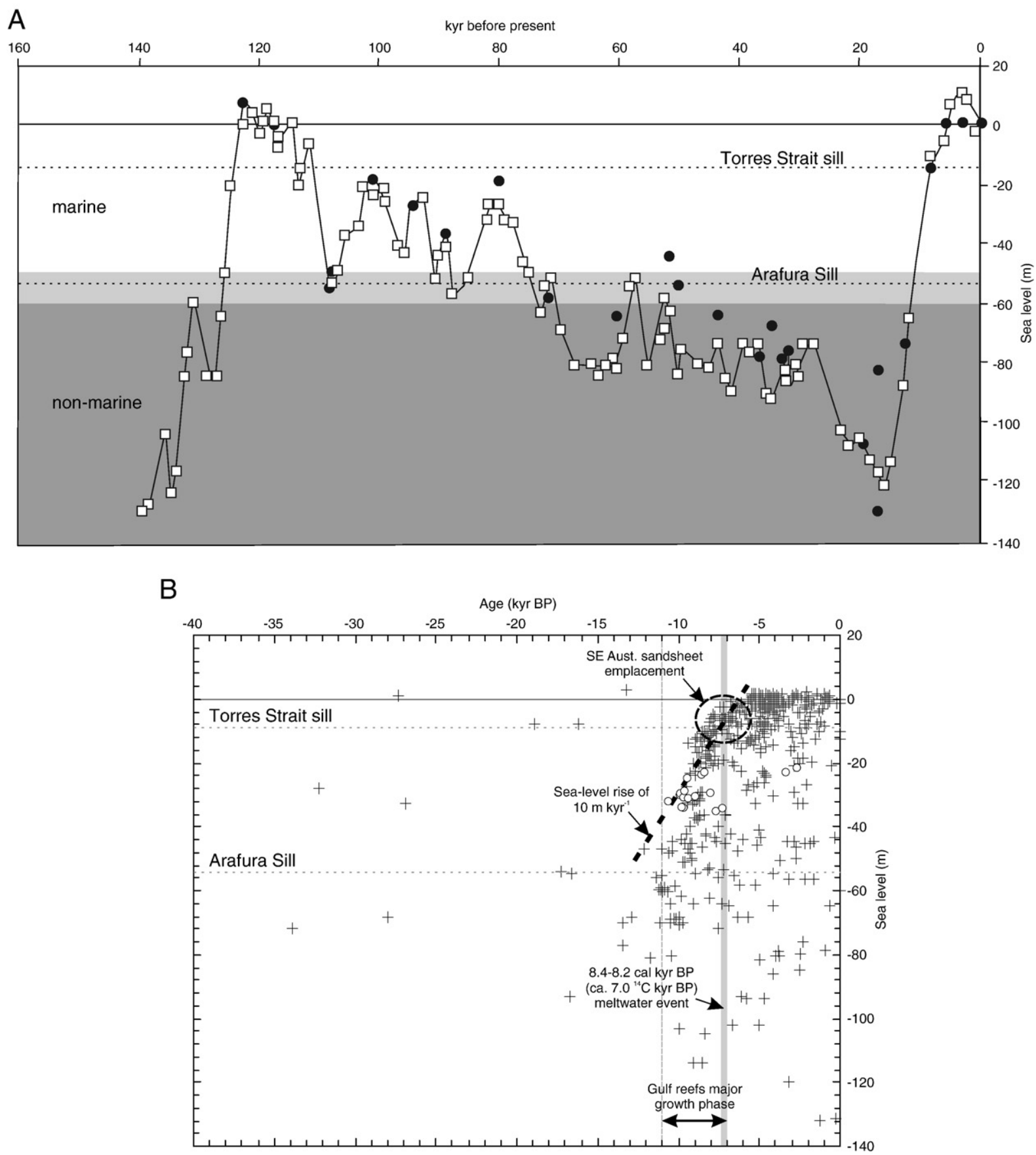

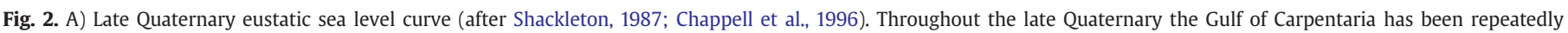

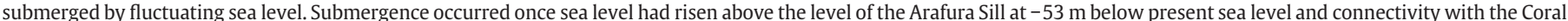

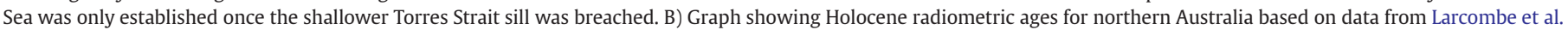

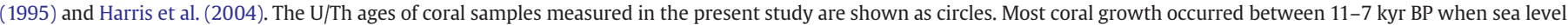

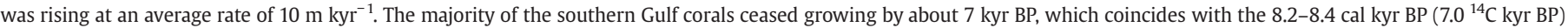

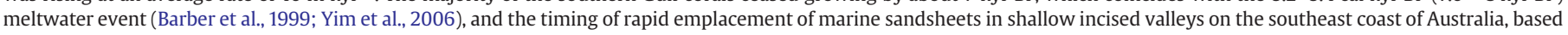
on data from Sloss et al. (2007).

1993). This circulation pattern implies weak connectivity with other major reef provinces outside of the Gulf (Condie et al., 2005).

The Gulf of Carpentaria experiences a tropical climate, with a hot, wet summer monsoon season and a warm, dry winter trade-wind season (Forbes, 1984). During summer (December-February), air temperature ranges from 24 to $36{ }^{\circ} \mathrm{C}$ and rainfall averages 600 $800 \mathrm{~mm}$, whereas during winter (June-August) air temperature ranges from 15 to $30{ }^{\circ} \mathrm{C}$ and rainfall averages $25 \mathrm{~mm}$ (Australian Bureau of Meteorology, www.bom.gov.au). The summer monsoon season is also associated with tropical cyclones once every 10 to $15 \mathrm{yr}$
(Lourensz, 1981) that are known to affect reef growth in other areas (Done, 1992).

\section{Methods}

Data reported here were collected during survey SS04/2005 (Geoscience Australia survey 276) on board Australia's Research Vessel Southern Surveyor during March-April, 2005 (Harris et al., 2007). During the survey, multibeam sonar mapping was undertaken to define the submerged coral reefs at four locations in the southern Gulf, and 


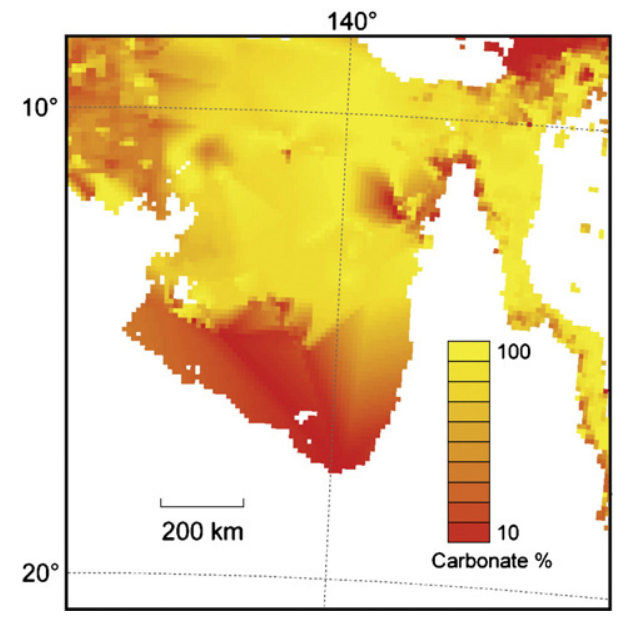

Fig. 3. Map showing distribution of carbonate content in the Gulf of Carpentaria. The southern Gulf is Australia's largest shelf province of terrigenous-dominated sediment. The area where the non-carbonate content is $>50 \%$ is more than $100,000 \mathrm{~km}^{2}$.

complement mapping work completed in 2003 (Harris et al., 2004). Rotary drill cores were also collected at all of the known coral reef locations to obtain material suitable for radiometric dating. An underwater video camera was used to obtain footage of the seabed environments. Sedimentological and geochemical assays, and 20-30 second snippets of the underwater video footage can be accessed from Geoscience Australia's national marine samples database (www.ga.gov. au/oracle/mars).

\subsection{Multibeam sonar}

Two multibeam sonar systems were used simultaneously on the survey: the ship's Simrad EM-300 $30 \mathrm{kHz}$ system, and a portable Reson-8101 240 kHz system. An Applied Microsystems Ltd SV PLUS acoustic velocity profiler was used to measure the acoustic velocity of the seawater, which ranged from 1542 to $1546 \mathrm{~m} \mathrm{~s}^{-1}$ in the study area. Data were corrected for tidal elevation, and spurious data and other artefacts were removed on board using Caris ${ }^{\mathrm{TM}}$ software. Bathymetric maps of the submerged coral reefs were generated with a nominal grid spacing of $10 \mathrm{~m}$ for interpretation of geomorphology. Multibeam mapping results for Reefs R1 to R3 were described by Harris et al. (2004) and by Heap et al. (2006). New results for Reefs R4 to R7 are presented here.

\subsection{Rotary-drill cores}

Limestone cores were recovered using a portable rotary drill capable of taking cores of up to $3 \mathrm{~m}$ length in water depths of up to $50 \mathrm{~m}$. For our survey, it was equipped with a diamond cutting bit, $75 \mathrm{~mm}$ diameter drill pipe (50 mm diameter core liner) and waterpumping system. Seawater was continuously flushed through the drill bit to keep it clear of debris. Hydraulic legs were used to level the $2000 \mathrm{~kg}$ drill frame and to apply pressure to the drill head, as necessary. Drilling was undertaken at speeds of around $30 \mathrm{rpm}$. The drill speed and hydraulic systems were all operated remotely from a control panel on board the ship. Stopping and starting of the drill was sometimes used to break the drill bit free from obstructions and improve penetration. Sensors on the derrick monitored the depth and speed of vertical penetration into the seabed.

\subsection{Core description and sampling}

In the laboratory the cores were logged and photographed, with one half kept as an archive while the other was sampled for laboratory analyses. The limestone cores were classified according to the scheme of Dunham (1962). Depositional textures were described according to Embry and Klovan (1971) and any solution unconformities (i.e. the boundary between the Holocene and Pleistocene sections) or other physical features noted. Sub-samples were taken for thin section (which aided in the classification of the limestone and description of sediment composition) and X-ray diffraction (XRD) analysis.

\subsection{U/Th age determinations of coral samples}

Samples of coral comprising $>95 \%$ aragonite (determined by XRD analysis) were selected for U-series age determinations. These samples were split into small 5-10 g sub-samples and contaminants were removed manually. In addition, another five samples with intact coral structure, but having a calcite mineralogy, were analysed for exploratory purposes and to constrain minimum ages for the coral reefs. The cleaned sub-samples were then pre-treated for U/Th age determinations according to the method described by McCulloch and Mortimer (in press). $\mathrm{U}$ and Th isotopic compositions were determined on each sub-sample using the Thermo Finnegan "Neptune" multicollector inductively coupled plasma mass spectrometer (MC-ICPMS) at the Research School of Earth Sciences, Australian National University. For MC-ICPMS U-Th dating the carbonate samples were dissolved in $\mathrm{HNO}_{3}$ and a mixed ${ }^{229} \mathrm{Th}-{ }^{233} \mathrm{U}$ spike was added. The Th and $U$ fractions were extracted and separated using a micro ion exchange column (TRU spec resin). Th and $U$ isotope measurements

Table 1

Details of rotary-drill cores collected from the submerged reefs

\begin{tabular}{|c|c|c|c|c|c|}
\hline Reef & Core & Latitude & Longitude & Water depth (m) & Core length (m) \\
\hline \multirow[t]{7}{*}{$\mathrm{R} 1$} & RD01 & -15.296 & 140.325 & 26.8 & 2.55 \\
\hline & RD02 & -15.275 & 140.336 & 26.4 & 1.60 \\
\hline & RD03 & -15.252 & 140.308 & 30.8 & 0.47 \\
\hline & RD04 & -15.321 & 140.291 & 26.4 & 1.06 \\
\hline & RD05 & -15.323 & 140.310 & 23.2 & 0.10 \\
\hline & RD06 & -15.322 & 140.310 & 23.2 & 0.48 \\
\hline & RD07 & -15.329 & 140.304 & 26.4 & 1.88 \\
\hline \multirow[t]{2}{*}{$\mathrm{R} 2$} & RD08 & -15.439 & 140.166 & 29.2 & 0.63 \\
\hline & RD09 & -15.448 & 140.170 & 26.4 & 0.78 \\
\hline \multirow[t]{3}{*}{ R3 } & RD10 & -15.515 & 140.110 & 30.8 & 0.17 \\
\hline & RD11 & -15.515 & 140.110 & 30.4 & 0.97 \\
\hline & RD12 & -15.523 & 140.114 & 20.2 & 2.19 \\
\hline \multirow[t]{12}{*}{ R4 } & RD14 & -16.001 & 139.097 & 23.6 & 0.82 \\
\hline & RD15 & -15.994 & 139.092 & 22.0 & 0.62 \\
\hline & RD16 & -15.980 & 139.108 & 19.6 & 0.63 \\
\hline & RD17 & -15.988 & 139.085 & 23.6 & 0.81 \\
\hline & RD18 & -16.017 & 139.124 & 25.6 & 0.76 \\
\hline & RD19 & -16.009 & 139.124 & 25.2 & 0.42 \\
\hline & RD20 & -15.963 & 139.135 & 29.6 & 0.42 \\
\hline & RD21 & -16.051 & 139.031 & 18.4 & 1.10 \\
\hline & RD22 & -16.055 & 139.024 & 20.0 & 0.26 \\
\hline & RD23 & -16.067 & 139.067 & 27.2 & 0.28 \\
\hline & RD24 & -16.048 & 139.052 & 26.4 & 1.26 \\
\hline & RD25 & -15.951 & 139.169 & 38.0 & 0.36 \\
\hline \multirow[t]{2}{*}{ R6 } & RD26 & -15.468 & 137.919 & 19.2 & 1.25 \\
\hline & RD27 & -15.463 & 137.915 & 29.6 & 1.05 \\
\hline \multirow[t]{3}{*}{ R7 } & RD28 & -15.489 & 137.631 & 29.2 & 1.22 \\
\hline & RD29 & -15.472 & 137.637 & 31.6 & 0.84 \\
\hline & RD30 & -15.486 & 137.624 & 25.6 & 0.78 \\
\hline \multirow[t]{13}{*}{ R5 } & RD31 & -15.723 & 138.879 & 19.2 & 1.49 \\
\hline & RD32 & -15.722 & 138.884 & 16.4 & 2.06 \\
\hline & RD33 & -15.699 & 138.899 & 25.2 & 0.86 \\
\hline & RD34 & -15.683 & 138.915 & 44.0 & 1.58 \\
\hline & RD35 & -15.664 & 138.895 & 30.4 & 0.78 \\
\hline & RD36 & -15.667 & 138.880 & 26.4 & 0.53 \\
\hline & RD37 & -15.694 & 138.861 & 24.8 & 0.58 \\
\hline & RD38 & -15.651 & 138.829 & 29.2 & 2.51 \\
\hline & RD39 & -15.630 & 138.854 & 27.6 & 0.62 \\
\hline & RD40 & -15.619 & 138.864 & 30.8 & 0.81 \\
\hline & RD41 & -15.602 & 138.817 & 26.0 & 0.61 \\
\hline & RD42 & -15.602 & 138.782 & 29.6 & 0.60 \\
\hline & RD43 & -15.583 & 138.785 & 24.0 & 0.73 \\
\hline
\end{tabular}


Table 2

Mineralogy and uranium-series ages of corals from the rotary-drill cores

\begin{tabular}{|c|c|c|c|c|c|c|c|c|c|c|c|}
\hline Core & Core depth (m) & Mineralogy $^{\mathrm{a}}$ & $\mathrm{U}(\mathrm{ppm})$ & ${ }^{230} \mathrm{Th}(\mathrm{ppt})$ & ${ }^{232} \mathrm{Th}(\mathrm{ppb})$ & $\delta{ }^{234} \mathrm{U}_{0}(\%)^{\mathrm{b}}$ & ${ }^{230} \mathrm{Th} /{ }^{238} \mathrm{U}$ & ${ }^{230} \mathrm{Th} /{ }^{232} \mathrm{Th}$ & Age (kyr) & Age (kyr) cor & $\delta^{234} \mathrm{U}_{T}(\% \circ)^{\mathrm{b}}$ \\
\hline \multirow[t]{2}{*}{ RD01 } & $0.39-0.40$ & arag. (99.8\%) & 2.8 & 4.26 & 7.58 & $146.7 \pm 0.9$ & $0.09480 \pm 0.00035$ & 105 & $9.367 \pm 0.036$ & $9.285 \pm 0.077$ & $150.7 \pm 0.9$ \\
\hline & $0.84-0.85$ & calc. (major) & 1.8 & 25.01 & 58.23 & $111.7 \pm 1.1$ & $0.86984 \pm 0.00350$ & 81 & $158.50 \pm 1.40$ & $158.03 \pm 1.6$ & $175.1 \pm 1.6$ \\
\hline \multirow[t]{2}{*}{ RD07 } & $0.53-0.54$ & arag. (98.3\%) & 2.4 & 3.85 & 3.45 & $145.0 \pm 1.6$ & $0.09744 \pm 0.00054$ & 209 & $9.650 \pm 0.056$ & $9.608 \pm 0.077$ & $149.0 \pm 1.6$ \\
\hline & $0.94-0.95$ & calc. $(17.1 \%)$ & 2.0 & 24.05 & 3.88 & $118.2 \pm 1.1$ & $0.74103 \pm 0.00162$ & 1163 & $114.93 \pm 0.48$ & $114.89 \pm 0.5$ & $163.7 \pm 1.5$ \\
\hline RD08 & $0.37-0.38$ & arag. (99.2\%) & 3.2 & 5.13 & 13.20 & $145.9 \pm 1.5$ & $0.09877 \pm 0.00041$ & 73 & $9.784 \pm 0.044$ & $9.661 \pm 0.105$ & $150.0 \pm 1.5$ \\
\hline RD09 & $0.28-0.29$ & arag. (99.6\%) & 2.7 & 3.93 & 0.25 & $145.9 \pm 1.2$ & $0.09065 \pm 0.00061$ & 2895 & $8.950 \pm 0.061$ & $8.947 \pm 0.062$ & $149.6 \pm 1.2$ \\
\hline \multirow[t]{3}{*}{ RD12 } & $0.19-0.20$ & arag. (100\%) & 2.1 & 2.89 & 0.31 & $148.0 \pm 1.4$ & $0.08506 \pm 0.00038$ & 1753 & $8.359 \pm 0.040$ & $8.355 \pm 0.042$ & $151.6 \pm 1.4$ \\
\hline & $0.90-0.91$ & arag. (99.7\%) & 2.0 & 2.82 & 1.93 & $148.0 \pm 1.6$ & $0.08679 \pm 0.00037$ & 274 & $8.535 \pm 0.040$ & $8.506 \pm 0.054$ & $151.6 \pm 1.6$ \\
\hline & $1.76-1.77$ & arag. (98.7\%) & 3.2 & 4.90 & 1.26 & $145.9 \pm 1.1$ & $0.09540 \pm 0.00045$ & 728 & $9.436 \pm 0.048$ & $9.424 \pm 0.053$ & $149.9 \pm 1.1$ \\
\hline RD15 & $0.14-0.15$ & calc. $(100 \%)$ & 1.0 & 8.68 & 6.19 & $124.0 \pm 1.9$ & $0.56022 \pm 0.00163$ & 263 & $73.87 \pm 0.36$ & $73.73 \pm 0.43$ & $152.9 \pm 2.3$ \\
\hline RD18 & $0.31-0.32$ & arag. (98.0\%) & 3.6 & 5.83 & 4.73 & $145.5 \pm 0.5$ & $0.09953 \pm 0.00054$ & 231 & $9.870 \pm 0.055$ & $9.831 \pm 0.075$ & $149.7 \pm 0.5$ \\
\hline \multirow[t]{2}{*}{ RD26 } & $0.10-0.11$ & arag. (99.0\%) & 2.5 & 1.13 & 0.23 & $147.1 \pm 1.1$ & $0.02756 \pm 0.00029$ & 937 & $2.643 \pm 0.028$ & $2.640 \pm 0.029$ & $148.2 \pm 1.1$ \\
\hline & $1.23-1.24$ & arag. (97.7\%) & 2.3 & 1.29 & 10.32 & $146.8 \pm 1.0$ & $0.03480 \pm 0.00035$ & 23 & $3.349 \pm 0.037$ & $3.211 \pm 0.106$ & $148.2 \pm 1.1$ \\
\hline RD27 & $0.15-0.16$ & arag. (98.3\%) & 4.2 & 5.03 & 42.05 & $145.8 \pm 1.2$ & $0.07419 \pm 0.00037$ & 22 & $7.270 \pm 0.038$ & $6.966 \pm 0.190$ & $148.8 \pm 1.2$ \\
\hline RD28 & $0.44-0.45$ & arag. (98.4\%) & 3.5 & 5.46 & 15.28 & $147.4 \pm 1.0$ & $0.09770 \pm 0.00430$ & 67 & $9.661 \pm 0.046$ & $9.529 \pm 0.111$ & $151.5 \pm 1.0$ \\
\hline RD29 & $0.63-0.64$ & calc. (major) & 3.0 & 28.15 & 26.82 & $118.5 \pm 1.4$ & $0.58349 \pm 0.00764$ & 197 & $78.90 \pm 1.50$ & $78.70 \pm 1.6$ & $148.2 \pm 1.8$ \\
\hline RD30 & $0.78-0.79$ & arag. (95.4\%) & 2.7 & 4.44 & 14.32 & $146.7 \pm 1.1$ & $0.09987 \pm 0.00047$ & 58 & $9.892 \pm 0.048$ & $9.736 \pm 0.13$ & $150.8 \pm 1.1$ \\
\hline RD32 & $0.52-0.53$ & calc. (major) & 2.5 & 21.09 & 15.87 & $123.1 \pm 1.9$ & $0.51302 \pm 0.00136$ & 249 & $65.49 \pm 0.28$ & $65.35 \pm 0.36$ & $148.3 \pm 2.2$ \\
\hline RD33 & $0.61-0.62$ & arag. $(100 \%)$ & 3.2 & 4.17 & 9.95 & $147.1 \pm 1.1$ & $0.08152 \pm 0.00051$ & 79 & $8.000 \pm 0.051$ & $7.905 \pm 0.10$ & $150.5 \pm 1.0$ \\
\hline RD35 & $0.15-0.16$ & arag. (98.0\%) & 3.6 & 4.49 & 26.92 & $147.0 \pm 1.0$ & $0.07809 \pm 0.00046$ & 31 & $7.657 \pm 0.047$ & $7.429 \pm 0.16$ & $150.2 \pm 1.0$ \\
\hline RD37 & $0.53-0.54$ & arag. (99.8\%) & 2.9 & 4.53 & 10.12 & $149.7 \pm 0.8$ & $0.09739 \pm 0.00052$ & 84 & $9.610 \pm 0.053$ & $9.505 \pm 0.10$ & $153.8 \pm 0.8$ \\
\hline RD39 & $0.35-0.36$ & arag. (94.6\%) & 3.2 & 5.54 & 73.36 & $147.2 \pm 1.0$ & $0.10666 \pm 0.00057$ & 14 & $10.590 \pm 0.058$ & $9.911 \pm 0.40$ & $151.7 \pm 1.0$ \\
\hline
\end{tabular}

a arag. $=$ aragonite; calc. $=$ low-Mg calcite; major $=>90 \%$.

b arag. =aragonite; calc. =low-Mg calcite; major $=>90 \%$.
${ }^{234} \mathrm{U}_{0}=$ measured value; the initial value $\delta^{234} \mathrm{U}_{T}=\delta^{234} \mathrm{U}_{0} \mathrm{e}^{\lambda T}{ }_{234}$; where $T=$ age (in years) and $\lambda^{234}=2.835 \times 10^{-6} \mathrm{yr}^{-1}$.

are performed in four sequential steps utilising the high abundance energy filter (RPQ) in the central channel to increase sensitivity and reduce tailing corrections, as described in McCulloch and Mortimer (in press). The isotopes ${ }^{229} \mathrm{Th}$ and ${ }^{230} \mathrm{Th}$ were each measured in the central ion counter (with RPQ) concurrently with ${ }^{232} \mathrm{Th}$ and ${ }^{238} \mathrm{U}$ in Faraday cups taking advantage of multi-collection measurements in reducing errors from ion beam instabilities. The isotope ${ }^{234} \mathrm{U}$ was also measured in the ion counter concurrently with ${ }^{238} \mathrm{U},{ }^{235} \mathrm{U},{ }^{233} \mathrm{U}$ and ${ }^{232} \mathrm{Th}$ in Faraday cups. Mass fractionation corrections for ${ }^{229} \mathrm{Th} /{ }^{230} \mathrm{Th}$, ${ }^{229} \mathrm{Th} /{ }^{232} \mathrm{Th},{ }^{234} \mathrm{U} /{ }^{238} \mathrm{U}$ and ${ }^{233} \mathrm{U} /{ }^{238} \mathrm{U}$ ratios were undertaken using the naturally occurring ${ }^{235} \mathrm{U}$ and ${ }^{238} \mathrm{U}$ measured simultaneously in Faraday cups. Gains were measured statically by measuring ${ }^{234} U /{ }^{235} U$ in the SEM/Faraday system using the SRM 960 standard. The SRM 960 standard was measured at regular intervals (every $1-2 \mathrm{~h}$ ) depending on instrumental drift and the ultimate stability required for the bracketing of SEM gains. For further details of the MC-ICPMS U-Th methods see McCulloch and Mortimer (in press).

\subsection{Underwater video camera}

An underwater video camera system consisting of a Sony video camera inside an underwater housing mounted on a sled was used to characterise the seabed features. The camera was towed at 1-2 knots behind the vessel for 15 to $20 \mathrm{~min}$. The video data were then used to establish the presence and nature of coral reef communities, including the presence and relative abundance of live hard corals, and to characterise the associated benthic organisms. Underwater video results for Reefs R1 to R3 were described by Harris et al. (2004) and by Heap et al. (2006). Results for Reefs R4-R7 are described here.

\section{Results}

The three submerged coral reefs mapped in 2003 (Harris et al., 2004) are numbered here as Reefs R1, R2 and R3. In the present study, an additional four submerged coral reefs were discovered, numbered R4, R5, R6 and R7. A total of 42 cores were obtained from all seven submerged coral reefs (Table 1 ). Core recovery varied from 0.10 to $2.55 \mathrm{~m}$, with a total recovery of $39.5 \mathrm{~m}$ composed of limestone (see Harris et al., 2007, for detailed logs and photographs of the cores).
Coral samples yielded 22 U/Th age determinations (Table 2), and 1520 min of video footage of the seabed environments was recorded at all 67 stations. Reef morphology, composition, ages, and underwater video observations are described below. All reported water depths have been corrected for tidal variation and refer to chart datum (lowest astronomical tide; LAT).

\subsection{Reef R1}

Reef R1 is the largest ( $72.48 \mathrm{~km}^{2}$; Harris et al., 2004) and most easterly of the submerged coral reefs (Fig. 1). Underwater video footage at Reef R1 showed that stations could be classified as either: i) predominantly bare limestone substrate with a consistent, scattered coverage of sessile macro-fauna, including single soft corals (alcyonaceans), gorgonians, hard plate corals (e.g., Turbinaria sp.) and sponges; or ii) dominated by a diverse, complex, coral reef like coverage of macro-fauna, consisting of these same species groups, and often interspersed with small patches of bare substrate.

A total of seven cores (RD01-07) were recovered from the central platform (Table 1; Fig. 4A). Core penetration ranged from 0.10 to $2.55 \mathrm{~m}$ in water depths of 23.2 to $30.8 \mathrm{~m}$. Core RD01 was collected in the centre of the platform in a water depth of $26.8 \mathrm{~m}$. Cores RD02, RD04 and RD07 were all collected in a water depth of $26.4 \mathrm{~m}$, on the top of the slightly raised $(0.5 \mathrm{~m})$ marginal rim that occurs around much of the reef-perimeter. Core RD03 was collected in a water depth of $30.8 \mathrm{~m}$ on the northern end of a deeper platform that skirts the edge of the main reef. Cores RD05 and RD06 were collected on the top of a smaller raised platform at the southern end of the reef in a water depth of $23.2 \mathrm{~m}$.

All of the cores recovered Holocene coral limestone material. The Holocene reef varies in thickness between 0.33 and $0.86 \mathrm{~m}$. The samples give an extremely narrow range of initial $\delta^{234} U$ values mostly within analytical uncertainty of the seawater value (Fig. 5) attesting to the excellent preservation of these samples. This is attributed to the lack of exposure of these samples to surficial conditions. Ages of the coral sampled at the base of the Holocene section are $9367 \pm 36 \mathrm{yr}$ for Core RD01 and $9650 \pm 56$ yr for Core RD07 (Table 2). Four cores penetrated into Pleistocene limestone (Fig. 4A). In these cores, the Holocene-Pleistocene solution unconformity occurs between 26.7- 
$27.3 \mathrm{~m}$ depth. Ages of the Pleistocene reef are $158,500 \pm 1400 \mathrm{yr}$ for core RD01 and 114,930 $\pm 480 \mathrm{yr}$ for Core RD07 (Table 2). These are unreliable 'open system' ages because XRD analyses showed that these coral samples had been altered to calcite by meteoric diagenesis and the $\delta^{234} U$ values lie significantly above the seawater curve (Fig. 5).

\subsection{Reefs $R 2$ and $R 3$}

Reef R2 is located about $25 \mathrm{~km}$ to the southwest of Reef R1 (Fig. 4B) and covers an area of $5.54 \mathrm{~km}^{2}$ (Harris et al., 2004). The surrounding sea floor rises from depths of $45-50 \mathrm{~m}$ to $18 \mathrm{~m}$ on the shallowest part of the reef. The reef is roughly circular with two distinct surfaces at $\sim 30 \mathrm{~m}$ and $\sim 27 \mathrm{~m}$. The shallower surface is located to the south, is bounded by a ridge at $24 \mathrm{~m}$, and contains a peak at 18-20 m (Fig. 4B; Harris et al., 2004). Reef R3 is located about $40 \mathrm{~km}$ southwest of Reef R1 (Fig. 1) and covers an area of $1.56 \mathrm{~km}^{2}$. This reef is oval-shaped and, like Reef R2, has two distinct surfaces at $30.1 \mathrm{~m}$ and $18-20 \mathrm{~m}$ water depth (Harris et al., 2004). Underwater video footage at Reefs R2 and R3 showed a predominantly bare substrate with a consistent, scattered coverage of sessile macro-fauna, including single soft corals (alcyonaceans), gorgonians, hard plate corals (e.g., Turbinaria sp.) and sponges. Luxuriant framework coral reef growth was observed at the location of RD12.

Two cores were recovered from Reef R2 (Table 1; Fig. 4B). Core RD08 penetrated $0.63 \mathrm{~m}$ of coral on the northern margin in a water depth of $29.2 \mathrm{~m}$. A coral sample at $0.37-0.38 \mathrm{~m}$ core depth returned an age of $9784 \pm 44 \mathrm{yr}$ confirming this upper section as Holocene in age (Table 2). A solution unconformity was encountered at $0.40 \mathrm{~m}$ core depth, which is interpreted to be the Holocene-Pleistocene boundary. Core RD09 was collected from the northern edge of the shallower surface at a depth of $26.4 \mathrm{~m}$. It penetrated $0.78 \mathrm{~m}$ of Holocene reef

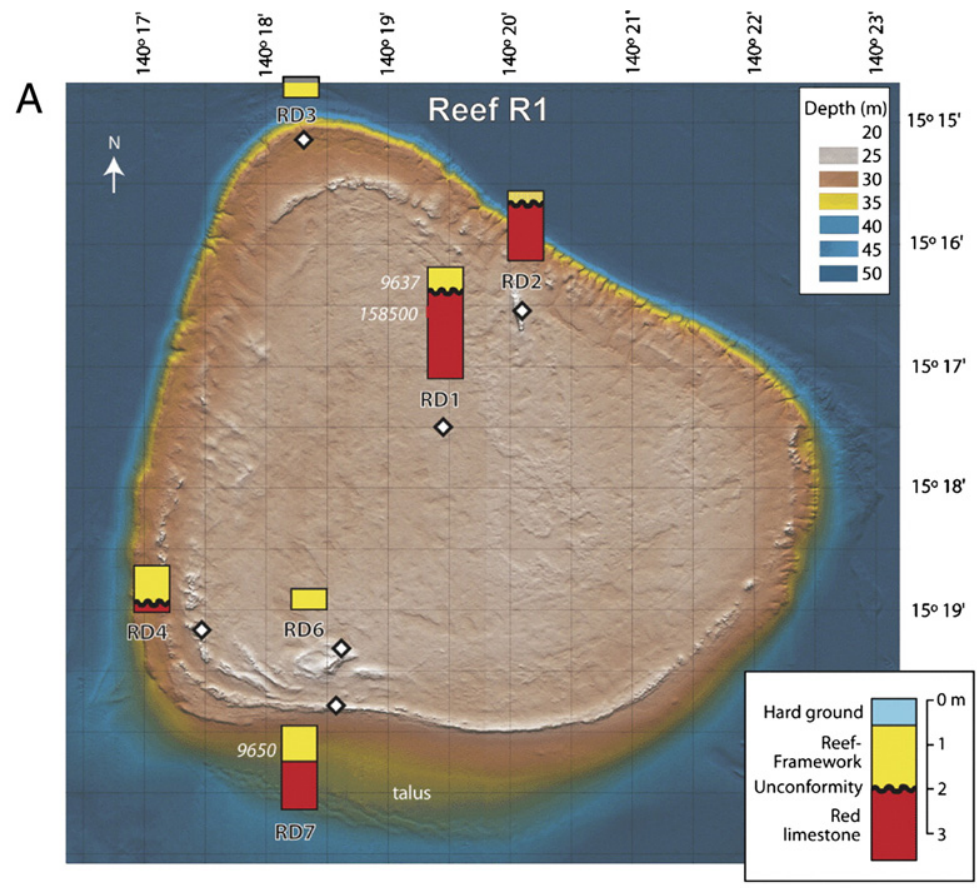

B

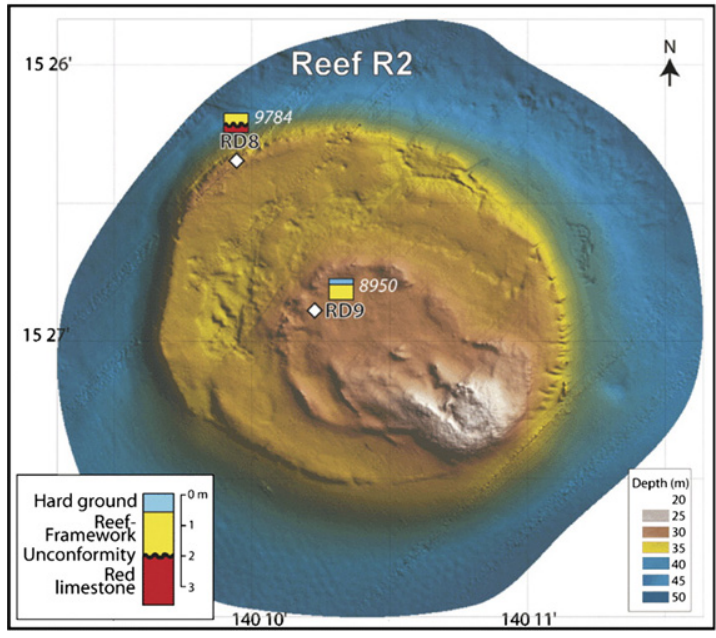

C

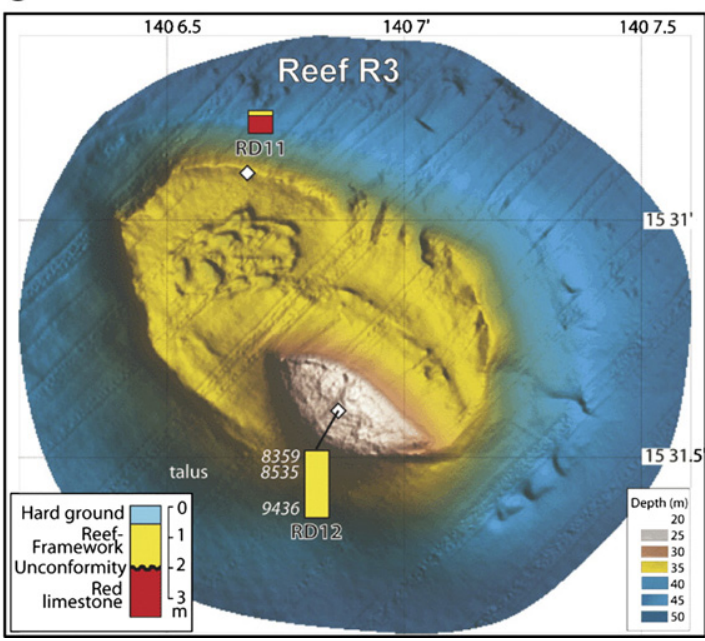

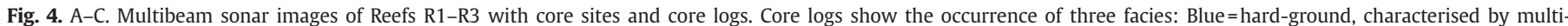

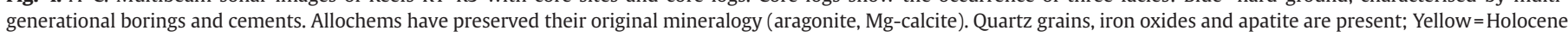

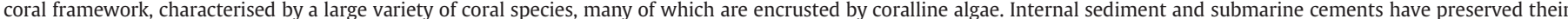

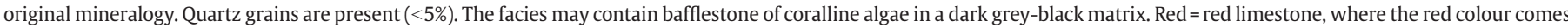

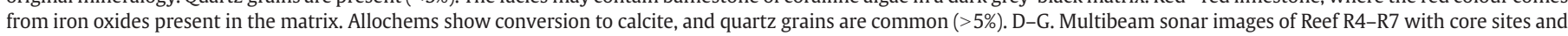
core logs. 

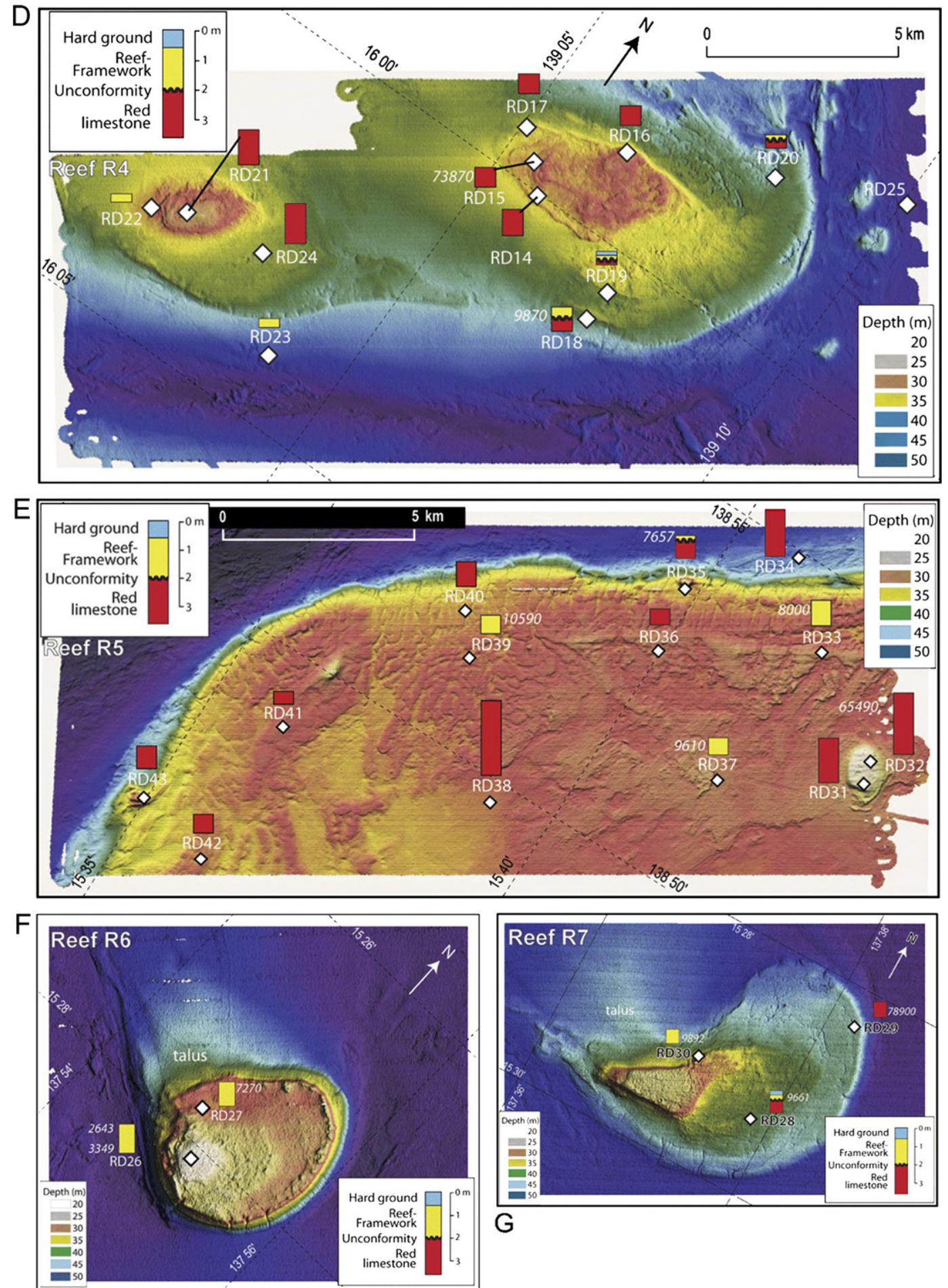

Fig. 4. (continued)

limestone. The upper $0.20 \mathrm{~m}$ of the core comprised an iron-stained, heavily bored rudstone consisting of fragments of coral, coralline algae and molluscs. An in situ coral (Acropora sp.) immediately beneath the rudstone at 0.28 to $0.29 \mathrm{~m}$ returned a U/Th age of $8950 \pm 61 \mathrm{yr}$ (Table 2). The remaining material from 0.29 to $0.78 \mathrm{~m}$ comprised boundstone/bafflestone consisting of branching coralline algae and gastropods in a dark grey matrix.

Two cores were recovered from Reef R3 (Table 1; Fig. 4C). Core $\mathrm{RD} 11$, located on the seaward edge of the deeper surface in a water depth of $30.4 \mathrm{~m}$, penetrated $\sim 0.19 \mathrm{~m}$ of unconsolidated (Holocene?) rudstone. The rudstone comprised fragments of coral and molluscs. Below $0.19 \mathrm{~m}$, a further $0.78 \mathrm{~m}$ of Pleistocene(?) reddish packstone was recovered. Core RD12, located on the shallower platform in a depth of $20.2 \mathrm{~m}$, penetrated $2.19 \mathrm{~m}$ of Holocene framestone comprised mainly of branching and platy corals (Fig. 4C). The framestone returned ages of $8359 \pm 40,8535 \pm 40$ and $9436 \pm 48$ yr at $0.19-0.20$, $0.90-0.91$ and $1.76-1.77 \mathrm{~m}$ down the core, respectively (Table 2$)$. The two intervals indicate accretion rates of $0.95 \mathrm{~m} \mathrm{kyr}^{-1}$ (from 9436 to $8535 \mathrm{yr}$ BP, 1.76 to $0.90 \mathrm{~m}$ core depth) and $4.0 \mathrm{~m} \mathrm{kyr}^{-1}$ (from 8535 to $8359 \mathrm{yr}$ BP, 0.90 to $0.20 \mathrm{~m}$ core depth). 


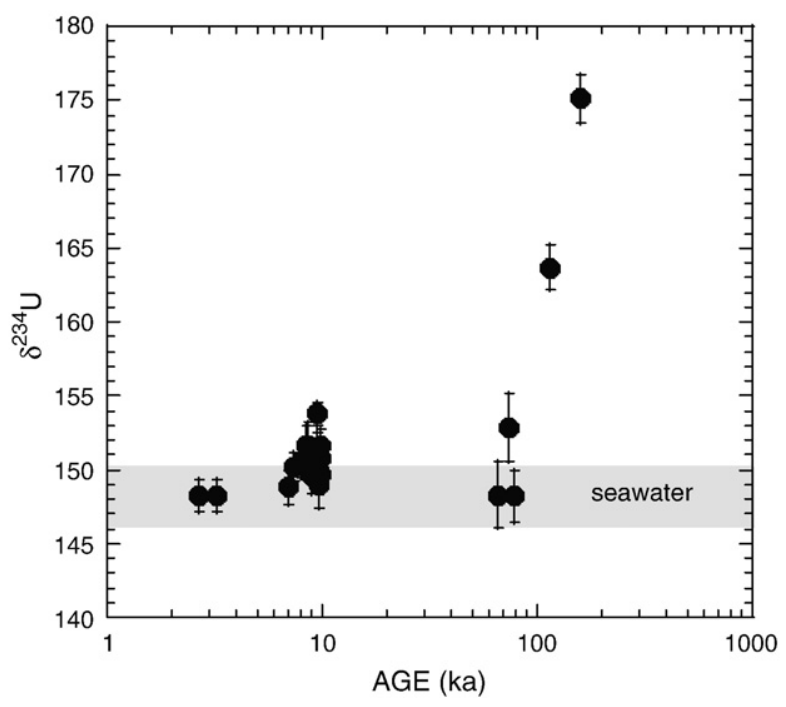

Fig. 5. Plot of $\delta^{234} U$ versus age for coral samples analysed in this study. The shaded area gives the standard range of $\delta^{234} \mathrm{U}$ for seawater (eg. McCulloch and Mortimer, in press).

\subsection{Reef $R 4$}

Reef R4 comprises two circular reef-like features (Fig. 4D) superimposed on the southern part of an elongate NW-trending platform that extends for about $100 \mathrm{~km}$ from Mornington Island (Fig. 1). On the northeastern margin of Reef R4 the sea floor rises from water depths of $45-50 \mathrm{~m}$ to $18 \mathrm{~m}$ onto the shallowest part of the platform.

Underwater video footage at Reef R4 showed predominantly bare substrate with a consistent, scattered coverage of sessile macro-fauna, including single soft corals (alcyonaceans), gorgonians, hard plate corals (e.g., Turbinaria sp.) and sponges. Although isolated patches of coral growth were rarely observed, framework coral reef growth was not observed at any of the locations.

Cores recovered from Reef R4 contained very little Holocene material (Table 1; Fig. 4D). Of the 11 cores recovered six contained no Holocene coral. The Holocene material occurred primarily on the deeper southern flank of the reef. Limestone recovered from Reef R4 comprised iron-stained packstone, framestone and unconsolidated rudstone, consisting of coral fragments, coralline algae and molluscs. A floatstone from $0.0-0.13 \mathrm{~m}$ in Core RD17 contained abundant root moulds, which are evidence of pedogenesis. A U/Th age of $73,870 \pm$ $360 \mathrm{yr}$ returned from identical deposits at $0.14-0.15 \mathrm{~m}$ core depth in Core RD15 confirms these deposits as Pleistocene in age (Table 2) and although altered to calcite the $\delta^{234} \mathrm{U}$ values give values within the seawater band.

In the five cores from reef $\mathrm{R} 4$ that contained limestone interpreted to be Holocene aged, three cores (RD18, 19 and 20) terminated in Pleistocene-aged coral (Fig. 4D). The thicknesses of Holocene reef in Cores RD18, 19 and 20 is $0.35,0.28$ and $0.19 \mathrm{~m}$, respectively. Although penetrating only $0.42 \mathrm{~m}$, Core RD19 consists of three distinct deposits. Iron-stained, unconsolidated rubble occurs from $0.0-$ $0.12 \mathrm{~m}$, which is interpreted as a hard-ground. This deposit overlies an unconsolidated sandy gravel bed from $0.12-0.28 \mathrm{~m}$ containing fresh coral. A solution unconformity occurs at $0.28 \mathrm{~m}$ core depth, below which a floatstone, with mud-supported, iron-stained limestone clasts occurs. Core RD22 recovered $0.26 \mathrm{~m}$ of unconsolidated carbonate gravel. Core RD23 recovered $0.28 \mathrm{~m}$ of mottled (oxidised) packstone containing abundant serpulids and other skeletal fragments. The deposits in Cores RD22 and 23 are interpreted to be Holocene in age based on these characteristics. Coral from 0.31$0.32 \mathrm{~m}$ core depth in Core RD18 returned an age of $9870 \pm 55 \mathrm{yr}$ confirming our Holocene interpretation of this deposit (Table 2).

\subsection{Reef $R 5$}

Reef R5 forms the northwestern-most part of the carbonate platform that extends from Mornington Island (Fig. 1). On the northeastern margin of Reef R5 the sea floor rises from 45-50 m water depth to 25-30 m on the platform. A $1 \mathrm{~km}$ diameter coral pinnacle attains a minimum depth of $16 \mathrm{~m}$ at the southern end of the platform (Fig. 4E). Reef morphology is indicated by the spur and groove features of the platform margin, and by the presence of concentric raised rims around the edges of the platform.

Underwater video footage at Reef R5 showed predominantly bare limestone substrate with a consistent, scattered coverage of sessile macro-fauna, including single soft corals (alcyonaceans), gorgonians, hard plate corals (e.g., Turbinaria sp.) and sponges. Although isolated patches of coral were rarely observed, none of the stations were characterised by framework coral reef growth.

The amount of Holocene material recovered in cores from Reef R5 was small, with only four of the 13 cores containing any Holocene section (Table 1; Fig. 4E). The thickness of the Holocene reefal material was $0.18 \mathrm{~m}$ in Core RD35, which was recovered on the outermost raised rim of the platform (Fig. 7), and comprised a single coral colony that returned an age of $7657 \pm 47 \mathrm{yr}$ at $0.15-0.16 \mathrm{~m}$ core depth (Table 2 ). Framework coral was sampled in Cores RD33, RD37 and RD39. Core RD33 recovered $0.86 \mathrm{~m}$ of coral framestone and a U/Th age at $0.61 \mathrm{~m}$ core depth returned an age of $8000 \pm 51$ yr (Table 2). Core RD37 recovered $0.58 \mathrm{~m}$ of coral framestone and a coral at $0.53-0.54$ core depth returned a U/Th age of $9610 \pm 53 \mathrm{yr}$ (Table 2). Core RD39 recovered $0.62 \mathrm{~m}$ of floatstone and a coral at $0.35-0.36 \mathrm{~m}$ core depth returned a $\mathrm{U} / \mathrm{Th}$ age of $10,590 \pm 58 \mathrm{yr}$ (Table 2 ). These ages indicate that the limestone contained in these cores is of Holocene age, with the coral in Core RD39 having the oldest Holocene age measured in this study.

Eight of the 13 cores collected from Reef $\mathrm{R} 5$ contained iron-stained limestone, indicative of subaerial exposure and diagenesis. Where corals have been identified in these cores, XRD analyses indicate that they have been altered to calcite. A calcite coral taken at $0.52-0.53 \mathrm{~m}$ core depth in RD32 returned a U/Th of age 65,490 \pm 285 yr. This minimum age, coupled with the iron-staining and calcite mineralogy, indicating that these deposits are of Pleistocene age.

\subsection{Reef $R 6$}

Reef R6 is located offshore of the Sir Edward Pellew islands approximately $250 \mathrm{~km}$ to the west of Reef R3 (Fig. 1). Reef R6 is an isolated patch coral reef, oval in plan view, about $2 \mathrm{~km}$ in diameter with a raised rim. The reef is characterised by a $30 \mathrm{~m}$ deep central platform and a shallower crest on the southwest corner that rises to $18 \mathrm{~m}$. A talus slope occurs on the western margin (Fig. 4F). Underwater video footage from Reef R6 showed a diverse, complex, framework coral reef, comprised of abundant Acropora sp., Turbinaria sp. plate, brain and staghorn corals.

The two cores collected from Reef R6 contained Holocene limestone (Table 1; Fig. 4F). The top of Core RD26, collected in a water depth of $19.2 \mathrm{~m}$, consists of an in situ pristine coral (Porites sp.?) that has been bored at the top and base by the endolithic bivalve Lithophaga sp. The remainder of the core consists of a framestone that is dominated by cobble-size corals and a minor amount of smaller coral fragments. In Core RD26, two U/Th ages from 0.10$0.11 \mathrm{~m}$ and $1.23-1.24 \mathrm{~m}$ core depth returned ages of $2643 \pm 28$ and $3349 \pm 37 \mathrm{yr}$, respectively (Table 2 ). These ages are the youngest Holocene ages measured in this study, and indicate a coral growth rate of about $1.6 \mathrm{~m} \mathrm{kyr}^{-1}$. Core RD27 was collected in a water depth of $29.6 \mathrm{~m}$ from the main platform. The core recovered $1.05 \mathrm{~m}$ of framework coral. A coral sample at $0.15-0.16 \mathrm{~m}$ core depth returned a U/Th age of $7270 \pm 38 \mathrm{yr}$, and confirmed this deposit to be Holocene in age (Table 2). 


\subsection{Reef $R 7$}

Reef R7 is located offshore of the Sir Edward Pellew islands approximately $30 \mathrm{~km}$ to the west of Reef R6 (Fig. 1). It is elongate and irregular in plan view, about $4 \mathrm{~km}$ in length, with a raised rim. The reef is characterised by a $30 \mathrm{~m}$ deep central platform and a shallower crest on the southwest corner that rises to $14 \mathrm{~m}$. A talus slope occurs on the western margin, spur and groove features are present on the reef margins, and karst erosion features occur on the central platform (Fig. 4G). Underwater video footage at Reef R7 showed predominantly bare limestone substrate, often covered with unconsolidated sediment. Gorgonians, hard plate corals (e.g. Turbinaria sp.) and sponges occur sparsely. Although some isolated patches of plate and staghorn coral growth were seen, none of the stations were characterised by framework coral reef growth.

Three cores were collected from Reef R7 (Table 1; Fig. 4G). Core RD28 consists of a weathered and iron-stained framestone of slightly bored branching corals and crustose coralline algae between 0.0 $0.55 \mathrm{~m}$ core depth. The matrix consists of internal sediments and quartz in micrite cement. Broken fragments of branching coral in a calcareous sandy matrix occur at the base of this section. A coral at 0.44-0.45 m core depth, which XRD analysis indicated as 100\% aragonite, returned a U/Th age of $9661 \pm 46 \mathrm{yr}$ (Table 2), confirming this upper limestone section as Holocene in age. A solution unconformity occurs at $0.55 \mathrm{~m}$ core depth below which the core contains a weathered iron-stained framestone comprising corals, coralline algae and internal sediment grains. Thin sections show that from 0.55-1.22 $\mathrm{m}$ core depth the limestone comprises an unaltered algal boundstone and fans of aragonite cement and a heavily ironstained packstone characterised by abundant dissolution of skeletal particles. The limestone section below the solution unconformity is interpreted to be Pleistocene in age based on the iron-staining and dissolution features. Core RD29 is wholly composed of weathered and iron-stained framestone, characterised by a large amount of cavity fill by reddish-brown, internal sediment. Larger cavities are filled with a red clay, and abundant silt- and sand-sized, angular to rounded, quartz grains. A coral at $0.63-0.64 \mathrm{~m}$ core depth, whose original skeleton has been completely replaced by neomorphic calcite, returned a U/Th age of $78,900 \pm 1500 \mathrm{yr}$ (Table 2). This minimum age indicates that the limestone in this core is Pleistocene in age. Core RD30 recovered $0.78 \mathrm{~m}$ of framestone, consisting of coral fragments encrusted by coralline algae and vermetids and in situ molluscs. A Porites sp. head at $0.78-0.79 \mathrm{~m}$ core depth returned a U/Th age of $9892 \pm 48 \mathrm{yr}$, indicating that the limestone in this core is Holocene in age (Table 2).

\subsection{Quartz grains in matrix}

Analysis of thin sections showed corals in Cores RD08, 18, 20, 26, $27,28,30,31,33,35$ and 39 contained abundant fine to medium quartz sand embedded in their matrix. In the Holocene-aged corals, the quartz grains are angular to well-rounded and comprise up to 5\% of the matrix. Concentrations of quartz are slightly higher in the Pleistocene-aged corals, attaining 15\%. These concentrations of terrigenous grains within the reef limestone matrix are in contrast to the Holocene reef limestones from the Great Barrier Reef which generally contain little, if any, terrigenous sediments (Woolfe and Larcombe, 1999). Deposition of quartz on the tops of reef platforms by fluvial or shallow marine processes is not consistent with the reef morphology, in which reef tops stand 15 to 20 above the level of surrounding seafloor. A possible explanation for the presence of relatively high concentrations of quartz grains in the limestone matrix of the southern Gulf of Carpentaria reefs is aeolian transport of dust from the adjacent mainland by the prevailing easterly and southeasterly winds. Dust storms have been observed to extend offshore into the Gulf on average once per year (McTainsh and Lynch, 1996).

\section{Discussion}

\subsection{Holocene history of the Carpentaria reefs - a new coral reef province in Australia}

All of the submerged bank features identified on nautical charts and selected for detailed multibeam sonar surveys in the present study (Reefs R4-R7) exhibit unequivocal evidence of coral reef morphology, consistent with the observations of Harris et al. (2004) for Reefs R1-R3. Furthermore, drilling and underwater video surveys have confirmed all seven reefs (R1-R7) to be composed of Holocene and Pleistocene coral limestone and to support varying degrees of live coral.

Based on the U/Th age determinations from coral samples, it is evident that reef growth commenced shortly after the Pleistocene pedestals were submerged by rising sea level during the early Holocene. According to our data, coral growth commenced by around 10.5 to $9.5 \mathrm{kyr} \mathrm{BP}$ on all seven of the reefs and was therefore regionally widespread. Reef growth persisted for $\sim 2000 \mathrm{yr}$ but had ceased at most locations by $\sim 7 \mathrm{kyr}$ BP. This is shown not only by the distribution of coral U/Th ages (Table 2) and the thickness of Holocene-aged coral limestone deposits encountered in our drill cores (Fig. 4A-G), but also by the underwater video footage, which indicates that present-day luxuriant framework reef growth is observed only on Reef R6 and sparsely on Reef R3. Late Holocene reef growth was measured only on Reef R6, which could indicate that part of this reef has regenerated, while the other reefs have not.

Since 7 kyr BP, coral growth has not resulted in the deposition of significant amounts of framework reef limestone, and the reefs have remained submerged 14 to $30 \mathrm{~m}$ below present sea level. The relatively thin veneer of Holocene limestone has been bored by benthic animals and the reef limestone has become cemented to form local hard ground deposits. Elsewhere, there is no evidence of any Holocene reef deposition, which implies either local absence of reef growth (non-deposition) and/or erosion. Interestingly, Holocene reef growth was not always located on the reef crests (e.g., Reefs R4 and R5). The typical pattern of growth is initiation on the slightly raised marginal rims and then, soon after, growth within the central platform and crests. The underlying Pleistocene limestone is exposed at the surface at many locations, and hence the morphology of the reefs is mostly relict, and is the product of several episodes of reef growth.

The discovery of patch coral reefs in the southern Gulf of Carpentaria by Harris et al. (2004) and the present study now brings the total known coral reef area in the Gulf to $>300 \mathrm{~km}^{2}$. Available bathymetry data show there to be as many as 50 bathymetric highs in the southern Gulf of Carpentaria. If all of these highs are coral reefs, then the results of our study suggest that this region is a new major coral reef province in northern Australia. This is a remarkable situation considering the southern Gulf of Carpentaria was not previously known to contain significant coral reefs.

\subsection{Comparisons with other major coral reef provinces}

In comparison with other coral reef provinces in Australia, depths of the Pleistocene-Holocene unconformity in the Gulf of Carpentaria reefs (28-33 m) are among the deepest recorded (cf. 4 to $28 \mathrm{~m}$ in the GBR, for example; see Table 3). The initiation of Holocene coral growth was also earlier in the Gulf of Carpentaria than other locations. In the GBR, for example, initiation of Holocene framework coral growth occurred between 8.6-6.6 kyr BP for the outer shelf reefs, 9.9-6.9 kyr $\mathrm{BP}$ for the mid shelf reefs, and 7.8-6.3 kyr BP for the fringing reefs (based on $>750$ radiometric ages measured from $>160$ cores collected on $>50$ reefs; see Table 3; Hopley et al., 2007). Initiation of Holocene coral growth occurred at similar times to the GBR reefs in the other major reef provinces in Australia and coral atolls and fringing reefs in the Pacific and Indian Oceans (Table 3). Montaggioni (1988) suggests 
Table 3

Depths to Pleistocene foundations, time of initiation and average growth rates for Holocene corals in Australia and other major reef provinces

\begin{tabular}{|c|c|c|c|}
\hline $\begin{array}{l}\text { Reef } \\
\text { Province }\end{array}$ & $\begin{array}{l}\text { Depth to Pleistocene } \\
\text { foundations }(\mathrm{m})\end{array}$ & $\begin{array}{l}\text { Time of Holocene coral } \\
\text { initiation (kyr BP) }\end{array}$ & $\begin{array}{l}\text { Average vertical } \\
\text { growth rates }\left(\mathrm{m} \mathrm{kyr}^{-1}\right)\end{array}$ \\
\hline \multicolumn{4}{|l|}{ Australia } \\
\hline GBR & $5-28$ & $6.5-9.9$ & $3-8$ \\
\hline Ningaloo & $7-19$ & $\sim 7.5$ & 1.6 \\
\hline $\begin{array}{l}\text { Houtman- } \\
\text { Abrolhos }\end{array}$ & $4-26$ & $\sim 9.8$ & $3.3-10.2$ \\
\hline $\begin{array}{l}\text { Cocos- } \\
\text { Keeling }\end{array}$ & $6-16$ & $\sim 7.5$ & $>4$ \\
\hline $\begin{array}{l}\text { Lord Howe } \\
\text { Island }^{\mathrm{b}}\end{array}$ & $5-10$ & $\sim 6.2$ & $2-4.2$ \\
\hline Elizabeth & - & $\sim 6.5$ & $<1$ \\
\hline Middleton & $>8$ & $\sim 7.1$ & 2.6 \\
\hline $\begin{array}{l}\text { Gulf of } \\
\text { Carpentaria }\end{array}$ & $27.5-32.8$ & $\sim 10.5$ & $0.95-4$ \\
\hline \multicolumn{4}{|c|}{ Western Pacific ${ }^{\mathrm{C}}$} \\
\hline $\begin{array}{l}\text { New } \\
\text { Caledonia }\end{array}$ & $3-14$ & $7-8$ & $1.4-20$ \\
\hline $\begin{array}{l}\text { Pacific } \\
\text { Island Atolls }\end{array}$ & $6-30$ & $\sim 8.6$ & - \\
\hline Palau & $16-25$ & $\sim 8.3$ & $3-14$ \\
\hline \multicolumn{4}{|c|}{ Indian Ocean $^{\mathrm{d}}$} \\
\hline Mauritius & 16 & $\sim 8.2$ & $1-5$ \\
\hline Mayotte & 21.5 & $\sim 9.6$ & $1-5$ \\
\hline Réunion & $20-25$ & $>8$ & $1-5$ \\
\hline \multicolumn{4}{|l|}{ Caribbean $^{\mathrm{e}}$} \\
\hline Belize & $3-18$ & $7.3-5.5$ & $<2$ \\
\hline Puerto Rico & $12-28$ & $\sim 9.5$ & $1.5-6$ \\
\hline $\begin{array}{l}\text { Submerged } \\
\text { Reefs }\end{array}$ & $30-40$ & $\sim 11$ & 5.5 \\
\hline
\end{tabular}

a Woodroffe et al., 1991, 1994, 2000, 2004, 2005, 2006; Collins et al., 1993, 2002; Kennedy and Woodroffe, 2000; Wyrwoll et al., 2006; Hopley et al., 2007; this study.

b Kennedy et al. (2002) reported one coral sample from a water depth of $36 \mathrm{~m}$ having a radiocarbon age of $8820 \pm 120 \mathrm{yr}$ BP.

c Marshall and Jacobson, 1985; Cabioch et al., 1995; Kayanne et al., 2002.

d Camoin et al., 1997.

e Blanchon and Jones, 1995; Hubbard et al., 1997; Gischler and Hudson, 1998; Gischler, 2003.

similar timing for the initiation of Holocene coral reefs worldwide. By comparison, initiation of the Holocene corals in the Gulf of Carpentaria occurred as early as $10.5 \mathrm{kyr}$ BP, at least $1000 \mathrm{yr}$ before other major reef provinces. Since the Gulf of Carpentaria reefs had largely stopped growing by around $7 \mathrm{kyr}$ BP, they had completed the bulk of their growth before Holocene corals in the other reef provinces had started. Clearly, the history of Holocene coral growth in Australia is more complex than previously recognised.

The thin Holocene section in most of our drill cores (Fig. 4A-G) indicates that the period of coral growth on the southern Gulf of Carpentaria reefs was brief and growth rates were slow. Based on three measured intervals, reef growth (accretion) rates were from 0.95 to $4.0 \mathrm{~m} \mathrm{kyr}^{-1}$ (Table 3). Comparison with growth rates of corals from other major reef provinces indicates that the Gulf of Carpentaria corals were relatively slow growing (e.g., Montaggioni, 2000). Even at their maximum rate of $4 \mathrm{~m} \mathrm{kyr}^{-1}$, their growth rates were relatively slow compared with the average contemporaneous rate of sea level rise of $10 \mathrm{~m} \mathrm{kyr}^{-1}$ between 11-7 kyr BP (Larcombe et al., 1995; Fig. 2B). Slow growth rates explain the submerged nature of the reefs, with sea level outpacing vertical reef growth beginning 8-9 kyr BP. Even though we sampled the shallowest reef tops, where most of the coral growth occurred, the Holocene coral growth rates reported here are average rates. We recognise that coral growth histories can vary significantly between windward and leeward reef environments (e.g., Kleypas and Hopley, 1993), and between coral types; growth rates for low density branching corals are typically faster than for higher density head corals (Hopley et al., 2007). However, such differences could not be assessed across all of the reefs with our data due to the low numbers of suitable Holocene corals for age determinations and it is possible that some corals grew more quickly for very short periods.

\subsection{Reef hypsometry and regional reef growth}

Hypsometric curves for the southern Gulf of Carpentaria coral reefs reveal that the upper reef-limestone surfaces fall within two very closely grouped depth intervals (Fig. 6). Reefs R1, R4 and R6 have hypsometric peaks (i.e., extensive horizontal surfaces) at 25.8 to $27.8 \mathrm{~m}$, and reefs R2, R3 and R7 have hypsometric peaks at between 30.4 to 30.9 m (Fig. 6). Reef R2 exhibits bi-modal hypsometric peaks at 27.2 and $30.8 \mathrm{~m}$. To these data, we add the results of a multibeam survey of another submerged reef from the Arafura Sea which has peaks at similar water depths (Reef R8; Fig. 7). These elevations coincide with ages of approximately 9-10.5 kyr BP when compared with the Holocene sea level curve for Australia (Thom and Roy, 1983), and are in the period of Holocene reef growth for the southern Gulf of Carpentaria reefs according to our U/Th age determinations (Fig. 2B; Table 2).

Horizontal reef-limestone surfaces reflect a phase of coral growth in relation to a stable sea level. Hypsometric curves of individual reefs provide insights into past sea levels when reef growth was most widespread. The fact that very little Holocene coral was recorded on the reefs and Pleistocene corals crop out at the seabed (i.e. the reef morphology is largely relict) suggests significant reef development occurred prior to the Holocene. As discussed by Larcombe et al. (1995) and Harris (1999), evidence from radiocarbon dated coral and mangrove peat samples suggest that there may have been a minor pause, or deceleration in the rate of sea level rise around $8 \mathrm{kyr}$ BP. If this interpretation is correct, the reefs in the Gulf may have exploited the opportunity to achieve widespread colonisation and relatively rapid growth rates at around this time, when sea level was $>10 \mathrm{~m}$ below its present position.

The significance of these results for sea level reconstructions is in relation to our ability to accurately estimate the water depths corresponding to phases of previous reef growth over broad geographic

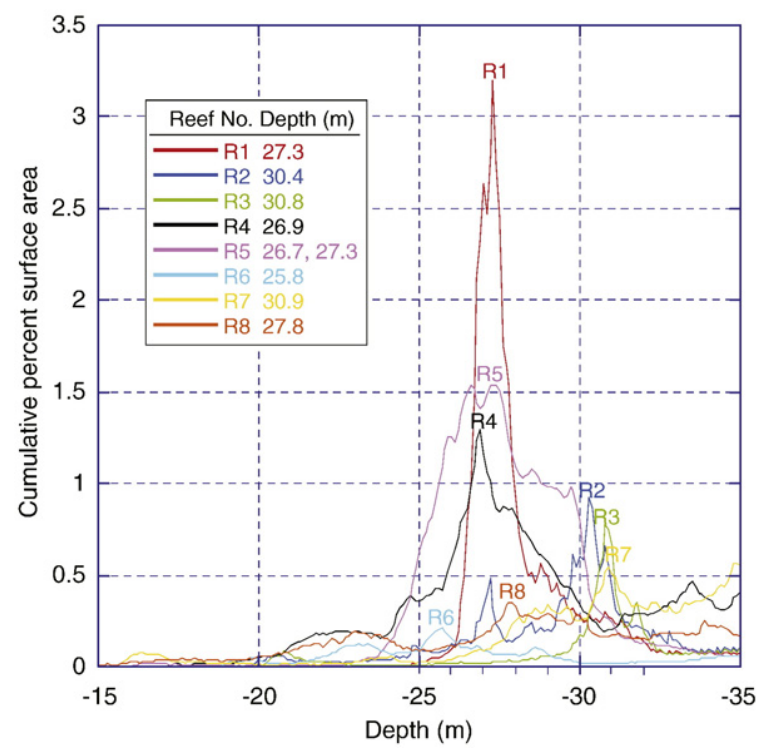

Fig. 6. Hypsometric curves for submerged reef platforms in the southern Gulf of Carpentaria (Reefs R1-R7) and the Arafura Sea (Reef R8). Water depths were derived from $10 \mathrm{~m}$ bathymetry grids and binned at $0.10 \mathrm{~m}$ intervals to estimate the total surface area within each bin; areas are normalised to the cumulative percentage area for each reef, to allow curves to be compared between reefs of different sizes. Modal depths for highest hypsometric peaks (most extensive surfaces) are listed for each reef. 


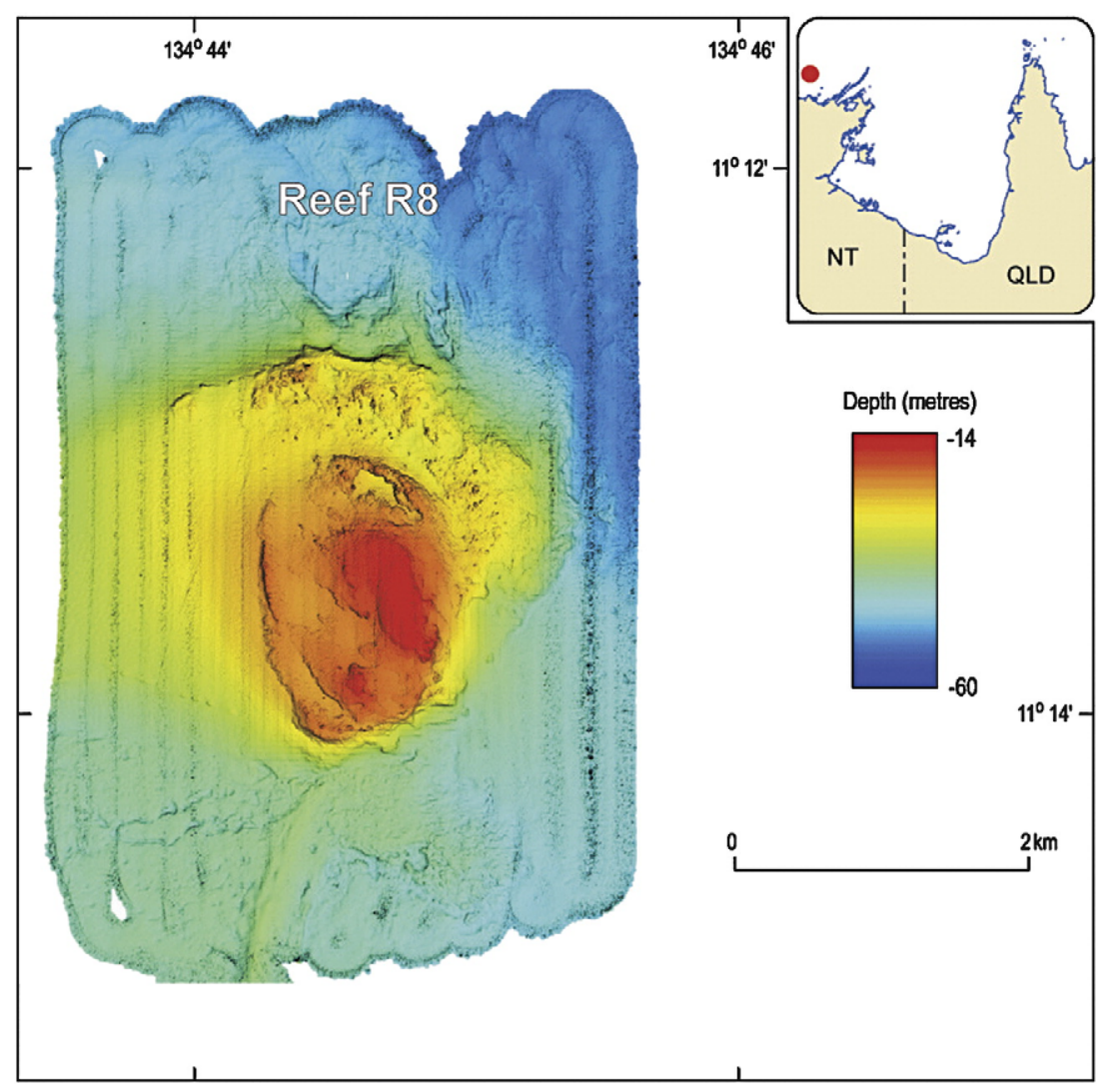

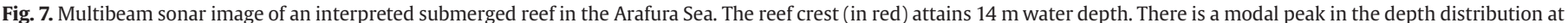
$28 \mathrm{~m}$ representing an extensive surface at that depth (Fig. 6). The existence of this reef implies that others may occur in this region.

areas. A regional signal is suggested by the close correspondence of surface elevations for reefs located many hundreds of kilometres apart. For example, Reefs R2 and R3 are located $280 \mathrm{~km}$ from Reef R7 (Fig. 1), but they have mean surface elevations (hypsometric modal peaks) within $0.5 \mathrm{~m}$ of each other (Fig. 6). Reef R8 in the Arafura Sea (Fig. 7) is over $750 \mathrm{~km}$ to the north of Reefs R1, R4 and R5 but they have mean surface elevations within $1 \mathrm{~m}$ of each other (Fig. 6). The similarity in these values suggests contemporaneous phases of reef growth over broad geographic regions. Our results also suggest that there has been imperceptible differential vertical displacement between the sites of these submerged reefs over the past $\sim 120 \mathrm{kyr}$.

\subsection{Possible explanations for the cessation of framework reef growth}

Having provided insights into the number, age and distribution of submerged coral reefs in the southern Gulf, an intriguing question still remains: What caused the near-total cessation of framework reef growth in the Gulf by around 7 kyr BP?

A number of factors could be responsible, including: rate of reef growth relative to sea level rise, changes in water turbidity, and/or a reduction in larval dispersion due to changes in water circulation (e.g., Montaggioni, 2000). Interestingly, cessation of reef growth (7-8 kyr $\mathrm{BP}$ ) occurs about the same time as the $8.4-8.2 \mathrm{cal} \mathrm{kyr}$ (ca. $7.0{ }^{14} \mathrm{C} \mathrm{kyr}$ BP) Antarctic meltwater event (Blanchon and Shaw, 1995; Barber et al., 1999; Yim et al., 2006; Liu et al., 2007) (Fig. 2B). The timing of the meltwater event also coincides with the rapid emplacement of widespread transgressive marine-derived sandsheets at the base of Holocene sequences in shallow incised-valleys in southeast Australia (Fig. 2B; Sloss et al., 2007), indicating deposition during a rapidly rising sea level. Rapidly rising sea level at this time $\left(>10 \mathrm{~m} \mathrm{kyr}^{-1}\right)$ could have drowned the reefs, which did not have sufficient fastgrowing framework coral to keep pace (cf., Blanchon and Shaw, 1995;
Blanchon et al., 2002). If this mechanism is responsible for the cessation of the reef growth in the Southern Gulf of Carpentaria then it is the first documented evidence of drowning by the 8.4-8.2 cal kyr meltwater event for Australian corals.

Despite the waters in the southern Gulf appearing turbid in underwater video footage and satellite images, measured suspended sediment concentrations are relatively low, ranging from 4-12 $\mathrm{mg} \mathrm{l}^{-1}$ (Harris et al., 2004; Heap et al., 2006; Harris et al., 2007). At 8 kyr BP sea level was 5-10 m below present (Thom and Roy, 1983) before rising rapidly to 1-2 $\mathrm{m}$ above present at $7 \mathrm{kyr}$ BP (Sloss et al., 2007). Taking the upper limit of $10 \mathrm{~m}$ below present at $8 \mathrm{kyr} \mathrm{BP}$, the reefs would have been located approximately $15 \mathrm{~km}$ closer to the coast at a distance of between 55 and $80 \mathrm{~km}$, with the reef surfaces in water depths of between 15-20 m. Currently, the coastal zone is turbid, with suspended sediment concentrations attaining $600 \mathrm{mg} \mathrm{l}^{-1}$ due to resuspension of bottom sediment by waves and suspended sediment delivered to the coast by local rivers (Ridd et al., 1988). It is therefore possible that, being closer to the coast, the reefs experienced conditions of higher turbidity 7-8 kyr BP and this contributed to the cessation of reef growth.

By 10.5 kyr BP, post-glacial sea level rise had reached $\sim 30$ m below present and the Gulf was a lagoon joined to the Arafura Sea. The coral stock that colonised the newly-submerged reef platforms was sourced from the Arafura Sea and not the Coral Sea, because the Torres Strait was still emergent at that time. By 9.0 kyr BP post-glacial sea level breached the $12 \mathrm{~m}$ deep Torres Strait sill (Harris, 1994) and soon after this the Gulf achieved its modern coastal configuration and water circulation system. It may be that the modern Gulf circulation is less effective at dispersing coral larvae (eg. Condie et al., 2005) and facilitating coral recruitment than the palaeo-gulf, "lagoon" mode, circulation, in which case reef growth would be inhibited by an unsteady supply of new colonisers. 
It is likely that no one factor was solely to blame for the cessation of coral reef growth, and a combination of factors was ultimately responsible. Factors such as coral physiology, as it relates to responding to environmental stresses, have also not been considered but most certainly would have played a part in the overall growth history of the reefs in the southern Gulf of Carpentaria.

\section{Conclusions}

Marine surveys in 2003 and 2005 have demonstrated that the Gulf of Carpentaria is a previously unrecognised major coral reef province in Australia. Multibeam sonar mapping, drill cores and underwater video have confirmed the existence of at least seven reefs composed of coral limestone that support living corals. As many as 50 other reefs may exist in the southern Gulf. Radiometric ages show that reef growth commenced shortly after limestone pedestals were submerged by rising sea level around $10.5 \mathrm{kyr}$ BP, making them the oldest Holocene coral reefs known in Australia. Reef growth persisted for $\sim 2.0 \mathrm{kyr}$ but it had ceased at most locations by $\sim 8.0 \mathrm{kyr}$ BP.

The elevations of reef surfaces indicate that Pleistocene reef growth occurred in relation to depths of 27 and $30 \mathrm{~m}$ below present mean sea level. These depths represent regionally significant phases of reef growth during a prolonged sea level still stand. Our U/Th age determinations indicate that only a brief phase of reef growth occurred during the Holocene, and our cores show that the underlying Pleistocene limestone is exposed in many locations. We conclude that the reefs are therefore mostly relict features, whose major phase of growth and development relates to an earlier, pre-Holocene sea level still stand.

We have no definite explanation for the cessation of widespread framework reef growth in the southern Gulf of Carpentaria by $7 \mathrm{kyr}$ BP. However, our measurements of reef growth rates $(0.95$ to $4 \mathrm{~m} \mathrm{kyr}^{-1}$ ), indicate that the reefs were unable to keep pace with contemporaneous rapid sea level rise $\left(>10 \mathrm{~m} \mathrm{kyr}^{-1}\right)$, which is consistent with a "give up" reef growth history.

\section{Acknowledgements}

Thanks to our colleagues Michael Hughes, Scott Nichol, Colin Woodroffe and an anonymous reviewer who provided comments on an earlier version of this paper, and also to the participants of GA Survey 276 aboard the RV Southern Surveyor who assisted with collecting the data. Survey 276 was funded in part by the National Oceans Office (now part of the Australian Government Department of Water, Environment, Heritage and the Arts). Published with permission of the Chief Executive Officer, Geoscience Australia.

\section{References}

Barber, D.C., Dyke, A., Hillaire-Marcel, C., Jennings, A.E., Andrews, J.T., Kerwin, M.W. Bilodeau, G., McNeely, R., Southon, J., Morehead, M.D., Gagnon, J.M., 1999. Forcing of the cold event of $8200 \mathrm{yr}$ ago by catastrophic drainage of Laurentide lakes. Nature 400, 344-348.

Blanchon, P., Jones, B., 1995. Marine-planation terraces on the shelf around Grand Cayman: a result of stepped Holocene sea-level rise. Journal of Coastal Research 11,1-33.

Blanchon, P., Jones, B., Ford, D.C., 2002. Discovery of a submerged relic reef and shoreline off Grand Cayman; further support for an early Holocene jump in sea level. Sedimentary Geology 147 (3-4), 253-270.

Blanchon, P., Shaw, J., 1995. Reef drowning during the last deglaciation: evidence for catastrophic sea-level rise and ice-sheet collapse. Geology 23, 4-8.

Cabioch, G., Montaggioni, L.F., Faure, G., 1995. Holocene initiation and development of New Caledonian fringing reefs, S.W. Pacific. Coral Reefs 14, 131-140.

Camoin, G.F., Colonna, M., Montaggioni, L.F., Thomassin, B.A., 1997. Holocene sea-level changes and reef development in the southwestern Indian Ocean. Coral Reefs 4, 231-246.

Chappell, J., Omura, A., Esat, T., McMulloch, M., Pandelfi, J., Ota, Y., Pillans, B., 1996. Reconciliation of Late Quaternary sea levels derived from coral terraces at Huon Peninsula with deep sea oxygen isotope records. Earth and Planetary Science Letters 141, 227-236.

Chivas, A.R., Garcia, A., van der Kars, S., Couapel, M.J.J., Holt, S., Reeves, J.M., Wheeler, D.J., Switzer, A.D., Murray-Wallace, C.V., Banerjee, D., Price, D.M., Wang, S.X., Pearson, G., Edgar, T., Beaufort, L., De Deckker, P., Lawson, E., Cecil, C.B., 2001. Sea-level and environmental changes since the last interglacial in the Gulf of Carpentaria, Australia: an overview. Quaternary International 83-85, 19-46.

Church, J.A., Forbes, A.M.G., 1981. Non-linear model of tides in the Gulf of Carpentaria Australian Journal of Marine and Freshwater Research 32, 685-697.

Church, J.A., Forbes, A.M.G., 1983. Circulation in the Gulf of Carpentaria, I, direct observations of currents in the southeast corner of the Gulf of Carpentaria. Australian Journal of Marine and Freshwater Research 34, 1-10.

Collins, L.B., Zhu, Z.R., Wyrwoll, K.H., Hatcher, B.G., Playford, P.E., Chen, J.H., Eisenhauer, A., Wasserburg, G.J., 1993. Late Quaternary evolution of coral reefs on a cool-water carbonate margin, the Abrolhos carbonate platforms, South-west Australia. Marine Geology 110, 203-212.

Collins, L.B., Zhu, Z.R., Wyrwoll, K.H., 1996. The structure of the Easter Platform, Houtman Abrolhos Reefs: Pleistocene foundations and Holocene reef growth. Marine Geology 135, 1-13.

Collins, L.B., Zhu, Z.R., Wyrwoll, K.H., Eisenhauer, A., 2002. Geological evolution of the northern Ningaloo Reef System during the late Quaternary. Proc 9th Int Coral Reef Symp, vol. 1, pp. 231-237.

Condie, S., Waring, J., Mansbridge, J.V., Cahill, M.L., 2005. Marine connectivity patterns around the Australian continent. Environmental Modelling and Software 20, 1149-1157.

Done, T.J., 1992. Effects of tropical cyclone waves on ecological and geomorphological structures on the Great Barrier Reef. Continental Shelf Research 12 (7/8), 859-872.

Dunham, R.J., 1962. Classification of carbonate rocks according to depositional texture. In: Ham, W.E. (Ed.), Classification of Carbonate Rocks. Memoir, vol. 1. American Association of Petroleum Geologists, Tulsa, Oklahoma, pp. 108-121.

Easton, A.K., 1970. The tides of the continent of Australia. Horace Lamb Centre for Oceanographic Research, Adelaide.

Embry, A.F., Klovan, J.E., 1971. A late Devonian reef tract on northeastern Banks Island, Northwest Territories. Bulletin of Canadian Petroleum Geology 19, 730-781.

Forbes, A.M.G., 1984. The contribution of local processes to seasonal hydrology of the Gulf of Carpentaria. Oceanographie Tropicale 19, 193-201.

Gischler, E., 2003. Holocene lagoonal development in the isolated carbonate platforms off Belize. Sedimentary Geology 159, 113-132.

Gischler, E., Hudson, J.H., 1998. Holocene development of three isolated carbonate platforms, Belize, Central America. Marine Geology 144, 333-347.

Harris, P.T., 1988. Sediments, bedforms and bedload transport pathways on the continental shelf adjacent to Torres Strait, Australia-Papua New Guinea. Continental Shelf Research 8, 979-1003.

Harris, P.T., 1994. Incised valleys and backstepping deltaic deposits in a foreland-basin setting, Torres Strait and Gulf of Papua, Australia. In: Dalrymple, R.W., Boyd, R. Zaitlin, B. (Eds.), Incised Valley Systems: Origin and Sedimentary Sequences. Special Publication, vol. 51. SEPM, Tulsa, Oklahoma, pp. 97-108.

Harris, P.T., 1999. Comment on Larcombe and Carter (1998) "Sequence architecture during the Holocene transgression: an example from the Great Barrier Reef shelf, Australia". Sedimentary Geology 125, 235-239.

Harris, P.T., Heap, A.D., Wassenberg, T., Passlow, V., 2004. Submerged coral reefs in the Gulf of Carpentaria, Australia. Marine Geology 207, 185-191.

Harris, P.T., Heap, A.D., Marshall, J., Hemer, M., Daniell, J., Hancock, A., Buchanan, C. Sbaffi, L., Brewer, D., Heales, D., 2007. Submerged coral reefs and benthic habitats of the southern Gulf of Carpentaria: Post-Survey Report - GA Survey 276, RV Southern Surveyor. Geoscience Australia, Record 2007/02. pp. 141.

Heap, A.D., Harris, P.T., 2008. Geomorphology of the Australian margin and adjacent seafloor. Journal of Earth Sciences 55 (4), 555-584.

Heap, A.D., Harris, P.T., Passlow, V., Wassenberg, T., Hughes, M., Sbaffi, L., Mathews, E. Fellows, M., Fountain, L., Porter-Smith, R., Daniell, J., Buchanan, C., Robertson, L., 2006. Geoscience Australia Survey 238 post-cruise report: Sources and sinks of terrigenous sediments in the southern Gulf of Carpentaria - RV Southern Surveyor 04/2003, May-June 2003. Geoscience Australia Record 2006/11. pp. 105.

Heyward, A., Pinceratto, E., Smith, L., 1997. Big Bank Shoals of the Timor Sea, an environmental resource atlas. BHP Petroleum, Melbourne. 115pp.

Hopley, D., Smithers, S.G., Parnell, K.E., 2007. The Geomorphology of the Great Barrier Reef: Development, Diversity and Change. Cambridge University Press, Cambridge. pp. 546.

Hubbard, D.K., Grill, I.P., Burke, R.B., Morelock, J., 1997. Holocene reef backstepping: southeastern Puerto Rico shelf. Proc 8th Int Coral Reef Symp, vol. 2, pp. 1779-1784.

Jones, M.R., 1986. Surficial sediments of the central Gulf of Carpentaria. Queensland Geological Survey Record 1986/40. pp. 36.

Jones, M.R., 1987. Surficial sediments of the western Gulf of Carpentaria. Australian Journal of Marine and Freshwater Research 38, 151-167.

Jones, M.R., Torgersen, T., 1988. Late Quaternary evolution of Lake Carpentaria on the Australia-New Guinea continental shelf. Australian Journal of Earth Sciences 35, 313-324.

Jones, B.G., Woodroffe, C.D., Martin, G.R., 2003. Deltas in the Gulf of Carpentaria Australia: forms, processes, and products. In: Sidi, F.H., Nummedal, D., Imbert, P., Darman, H., Posamentier, H.W. (Eds.), Tropical Deltas of Southeast Asia - Sedimentology, Stratigraphy, and Petroleum Geology. Special Publication, vol. 76. SEPM, Tulsa, pp. 21-43.

Kayanne, H., Yamano, H., Randall, R., 2002. Holocene sea-level changes and barrier reef formation on an oceanic island, Palau Islands, Western Pacific. Sedimentary Geology 150, 47-60.

Kennedy, D.M., Woodroffe, C.D., 2000. Holocene lagoonal sedimentation at the intertidal limits of reef growth, Lord Howe Island, Tasman Sea. Marine Geology 169, 287-304.

Kennedy, D.M., Woodroffe, C.D., Jones, B.G., Dickson, M.E., Phipps, C.V.G., 2002 Carbonate sedimentation on subtropical shelves around Lord Howe Island and Balls Pyramid, Southwest Pacific. Marine Geology 188, 333-349. 
Kleypas, J.A., Hopley, D., 1993. Reef development across a broad continental shelf southern Great Barrier Reef Australia. Proc 7th Int Coral Reef Symp, vol. 2, pp. 1129-1141.

Larcombe, P., Carter, R.M., Dye, J., Gagan, M.K., Johnson, D.P., 1995. New evidence for episodic post-glacial sea level rise, central Great Barrier Reef, Australia. Marine Geology 127, 1-44.

Liu, J., Saito, Y., Wang, H., Yang, Z., Nakashima, R., 2007. Sedimentary evolution of the Holocene subaqueous clinoform off the Shandong Peninsula in the Yellow Sea. Marine Geology 236, 165-187.

Lourensz, R.S., 1981. Tropical Cyclones in the Australian Region July 1909 to June 1980 second ed. Hedges and Bell Publishing Company for the Australian Bureau of Meteorology, Maryborough, Victoria. 89pp.

Marshall, J.F., Jacobson, G., 1985. Holocene growth of a mid-Pacific atoll: Tarawa, Kiribati. Coral Reefs 4, 11-17.

Macintyre, I.G., 1972. Submerged reefs of the eastern Carribean. American Association of Petroleum Geologists Bulletin 5, 49-53.

McCulloch, M.T. and Mortimer, G., in press. Applications of the 238U-230Th decay series to dating of fossil and modern corals using MC-ICPMS. Australian Journal of Earth Sciences.

McTainsh, G., Lynch, A., 1996. Quantitative estimates of the effect of climate change on dust storm activity in Australia during the Last Glacial Maximum. Geomorphology 17, 263-271.

Montaggioni, L., 1988. Holocene reef growth history in mid-plate high volcanic islands. Proc 6th Int Coral Reef Symp, vol. 3, pp. 455-460.

Montaggioni, L., 2000. Postglacial reef growth. Comptes Rendus de l'Académie des Sciences. Series IIA, Earth and Planetary Science 331, 319-330.

Nix, H.A., Kalma, J.D., 1972. Climate as a dominant control in the biogeography of northern Australia and New Guinea. In: Walker, D. (Ed.), Bridge and Barrier: The Natural and Cultural History of Torres Strait. Australian National University, Canberra, pp. 61-91.

Neumann, A.C., Macintyre, I.G., 1985. Reef response to sea level rise: keep-up, catch-up or give-up. 5th International Coral Reef Congress, Tahiti, International Coral Reef Society, pp. 105-110.

Ridd, P.V., Sandstrom, M.W., Wolanski, E., 1988. Outwelling from tropical tidal salt flats. Estuarine, Coastal and Shelf Science 26, 243-253.

Shackleton, N.J., 1987. Oxygen isotopes, ice volume and sea level. Quaternary Science Reviews 6, 183-190.

Sloss, C.R., Murray-Wallace, C.V., Jones, B.G., 2007. Holocene sea-level change on the southeast coast of Australia: a review. Holocene 17, 1001-1016.
Thom, B.G., Roy, P.S., 1983. Relative sea-levels and coastal sedimentation in southeast Australia in the Holocene. Journal of Sedimentary Petrology 55, 257-264.

Torgersen, T., Hutchinson, M.F., Searle, D.E., Nix, H.A., 1983. General bathymetry of the Gulf of Carpentaria and the Quaternary physiography of Lake Carpentaria. Palaeogeography, Palaeoclimatology, Palaeoecology 41, 207-225.

Torgersen, T., Luly, J., De Deckker, P., Jones, M.R., Searle, D.E., Chivas, A.R., Ullman, W.J., 1988. Late Quaternary environments of the Carpentaria Basin, Australia. Palaeogeography, Palaeoclimatology, Palaeoecology 67, 245-261.

Veron, J.E.N., 2000. Corals of the World, vol. 1. Australian Institute of Marine Science, Townsville. pp. 463.

Woodroffe, C.D., Veeh, H.H., Falkland, A.C., McLean, R.F., Wallensky, E., 1991. Last interglacial reef and subsidence of Cocos (Keeling) Islands, Indian Ocean. Marine Geology 96, 137-143.

Woodroffe, C.D., McLean, R.F., Wallensky, E., 1994. Geomorphology of the Cocos (Keeling) Islands. Atoll Research Bulletin 402,1-33.

Woodroffe, C.D., Kennedy, D.M., Hopley, D., Rasmussen, C.E., Smithers, S.G., 2000. Holocene reef growth in Torres Strait. Marine Geology 170, 331-346.

Woodroffe, C.D., Kennedy, D.M., Jones, B.G., Phipps, C.V.G., 2004. Geomorphology and Late Quaternary development of Middleton and Elizabeth Reefs. Coral Reefs 23, 249-262.

Woodroffe, C.D., Dickson, M.E., Brooke, B.P., Kennedy, D.M., 2005. Episodes of reef growth at Lord Howe Island, the southernmost reef in the southwest Pacific. Global and Planetary Change 49, 222-237.

Woodroffe, C.D., Kennedy, D.M., Brooke, B.P., Dickson, M.E., 2006. Geomorphological evolution of Lord Howe Island and carbonate production at the latitudinal limit of coral growth. Journal of Coastal Research 22, 188-201.

Woolfe, K.J., Larcombe, P., 1999. Terrigenous sedimentation and coral reef growth: a conceptual framework. Marine Geology 155, 331-345.

Wolanski, E., 1993. Water circulation in the Gulf of Carpentaria. Journal of Marine Systems 4, 401-420.

Wyrwoll, K.H., Zhu, Z.R., Collins, L.B., Hatcher, B.G., 2006. Origin of blue hole structures in coral reefs: Houtman Abrolhos, Western Australia. Journal of Coastal Research 22, 202-208.

Yim, W.W.-S., Huang, G., Fontugne, M.R., Hale, R.E., Paterne, M., Pirazzoli, P.A., Ridley Thomas, W.N., 2006. Postglacial sea-level changes in the northern South China Sea continental shelf: Evidence for a post-8200 calendar yr BP meltwater pulse. Quaternary International 145-146, 55-67. 